\title{
Comparison of Three Methods to Project Future Baseline Carbon Emissions in Temperate Rainforest, Curiñanco, Chile
}

Patrick Gonzalez

Antonio Lara ${ }^{2}$

Jorge Gayoso ${ }^{2}$

Eduardo Neira ${ }^{2}$

Patricio Romero ${ }^{2}$

Leonardo Sotomayor ${ }^{1}$

1 The Nature Conservancy, 4245 North Fairfax Drive, Arlington, VA 22203-1606 USA

2 Universidad Austral de Chile, Facultad de Ciencias Forestales, Isla Teja, Valdivia, Chile

July 14,2005

Topical Report

Award DE-FC-26-01NT41151

U.S. Department of Energy, National Energy Technology Laboratory, Morgantown, WV USA 


\section{Disclaimer}

This report was prepared as an account of work sponsored by an agency of the United States Government. Neither the United States Government nor any agency thereof, nor any of their employees, makes any warranty, express or implied, or assumes any legal liability or responsibility for the accuracy, completeness, or usefulness of any information, apparatus, product, or process disclosed, or represents that its use would not infringe privately owned rights. Reference herein to any specific commercial product, process, or service by trade name, trademark, manufacturer, or otherwise does not necessarily constitute or imply its endorsement, recommendation, or favoring by the United State Government or any agency thereof. The views and opinions of authors expressed herein do not necessarily state or reflect those of the United States Government or any agency thereof. 


\section{Comparison of Three Methods to Project Future Baseline Carbon Emissions in Temperate Rainforest, Curiñanco, Chile}

\section{Abstract}

Deforestation of temperate rainforests in Chile has decreased the provision of ecosystem services, including watershed protection, biodiversity conservation, and carbon sequestration. Forest conservation can restore those ecosystem services. Greenhouse gas policies that offer financing for the carbon emissions avoided by preventing deforestation require a projection of future baseline carbon emissions for an area if no forest conservation occurs. For a proposed $570 \mathrm{~km}^{2}$ conservation area in temperate rainforest around the rural community of Curiñanco, Chile, we compared three methods to project future baseline carbon emissions: extrapolation from Landsat observations, Geomod, and Forest Restoration Carbon Analysis (FRCA). Analyses of forest inventory and Landsat remote sensing data show 1986-1999 net deforestation of 1900 ha in the analysis area, proceeding at a rate of $0.0003 \mathrm{y}^{1}$. The gross rate of loss of closed natural forest was $0.042 \mathrm{y}^{-1}$. In the period 1986-1999, closed natural forest decreased from 20000 ha to 11000 ha, with timber companies clearing natural forest to establish plantations of non-native species. Analyses of previous field measurements of species-specific forest biomass, tree allometry, and the carbon content of vegetation show that the dominant native forest type, broadleaf evergreen (bosque siempreverde), contains $370 \pm$ $170 \mathrm{t} \mathrm{ha}^{-1}$ carbon, compared to the carbon density of non-native Pinus radiata plantations of $240 \pm 60 \mathrm{tha}{ }^{-1}$. The 1986-1999 conversion of closed broadleaf evergreen forest to open broadleaf evergreen forest, Pinus radiata plantations, shrublands, grasslands, urban areas, and bare ground decreased the carbon density from $370 \pm$ $170 \mathrm{t} \mathrm{ha}^{-1}$ carbon to an average of $100 \mathrm{tha}^{-1}$ (maximum $160 \mathrm{tha}^{-1}$, minimum $50 \mathrm{t} \mathrm{ha}^{-1}$ ). Consequently, the conversion released 1.1 million $t$ carbon. These analyses of forest inventory and Landsat remote sensing data provided the data to evaluate the three methods to project future baseline carbon emissions. Extrapolation from Landsat change detection uses the observed rate of change to estimate change in the near future. Geomod is a software program that models the geographic distribution of change using a defined rate of change. FRCA is an integrated spatial analysis of forest inventory, biodiversity, and remote sensing that produces estimates of forest biodiversity and forest carbon density, spatial data layers of future probabilities of reforestation and deforestation, and a projection of future baseline forest carbon sequestration and emissions for an ecologically-defined area of analysis. For the period 1999-2012, extrapolation from Landsat change detection estimated a loss of 5000 ha and $520000 \mathrm{t}$ carbon from closed natural forest; Geomod modeled a loss of 2500 ha and $250000 \mathrm{t}$; FRCA projected a loss of $4700 \pm 100$ ha and $480000 \mathrm{t}$ (maximum $760000 \mathrm{t}$, minimum $220000 \mathrm{t}$ ). Concerning labor time, extrapolation for Landsat required 90 actual days or 120 days normalized to Bachelor degree level wages; Geomod required 240 actual days or 310 normalized days; FRCA required 110 actual days or 170 normalized days. Users experienced difficulties with an MS-DOS version of Geomod before turning to the Idrisi version. For organizations with limited time and financing, extrapolation from Landsat change provides a cost-effective method. Organizations with more time and financing could use FRCA, the only method where that calculates the deforestation rate as a dependent variable rather than assuming a deforestation rate as an independent variable. This research indicates that best practices for the projection of baseline carbon emissions include integration of forest inventory and remote sensing tasks from the beginning of the analysis, definition of an analysis area using ecological characteristics, use of standard and widely used geographic information systems (GIS) software applications, and the use of species-specific allometric equations and wood densities developed for local species. 


\section{Comparison of Three Methods to Project Future Baseline Carbon Emissions in Temperate Rainforest, Curiñanco, Chile}

Table of Contents

Abstract
Introduction
Methods
Results and Discussion
Conclusion
References

List of Figures

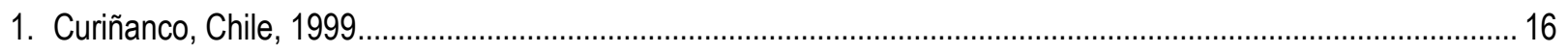

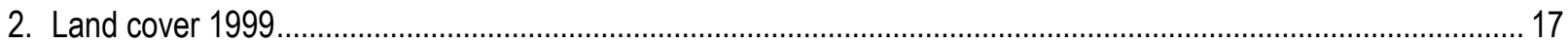

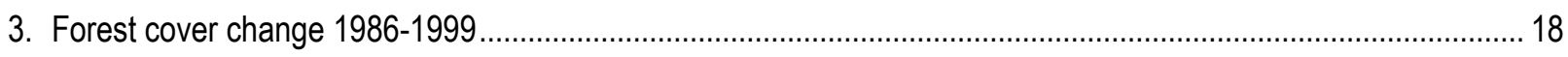

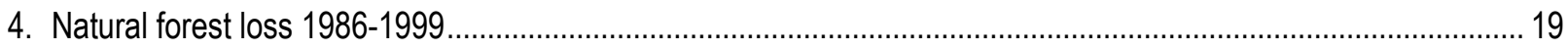

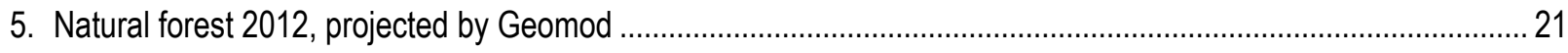

6. Probability functions of loss of closed natural forest for six factors, derived by FRCA .......................................... 23

7. Probability distribution of $1999-2012$ loss of closed natural forest, derived by FRCA ........................................... 24

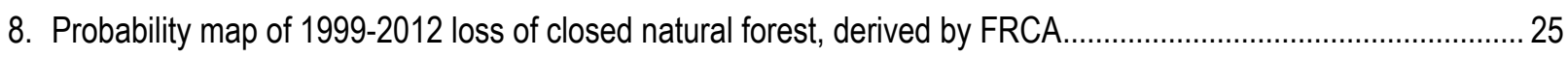

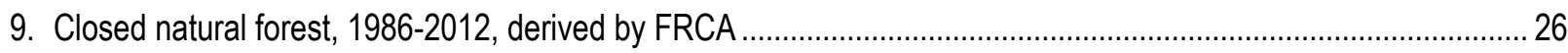

\section{List of Tables}

1. Allometric equations and wood densities for southern Chile tree species .......................................................... 14

2. Carbon density of natural temperate rainforest vegetation, Chile ....................................................................... 15

3. Carbon density of 16-year stands of Pinus radiata plantations in southern Chile.............................................. 15

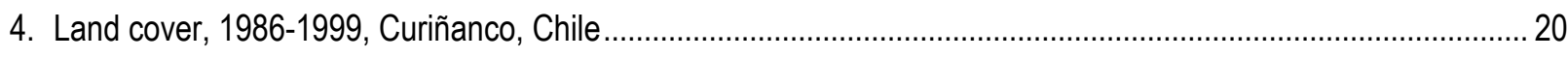

5. Gross changes in total forest area, 1986-1999 ............................................................................................. 20

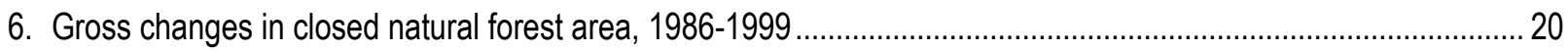

7. Forest carbon loss from conversion of closed natural forest ....................................................................... 21

8. Weight of deforestation factors, derived from principal components analysis ...................................................... 22

9. Probability functions of loss of closed natural forest for six factors, derived by FRCA ...................................... 22

10. Comparison of three estimates of change in closed natural forest area and forest carbon, 1999-2012................ 28

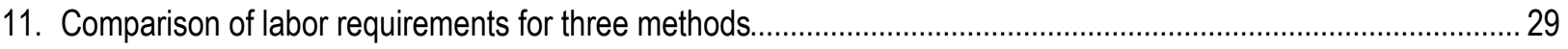




\section{Introduction}

Carbon emissions from human activities have increased to 8 billion $\mathrm{t}^{-1}$, more than twice the rate at which vegetation and oceans can naturally sequester carbon (IPCC 2001a). Increased carbon dioxide in the atmosphere has raised global mean surface temperature $0.6 \pm 0.2^{\circ} \mathrm{C}$ in the $20^{\text {th }}$ Century and could raise global mean surface temperature by $1.4-5.8^{\circ} \mathrm{C}$ in the $21^{\text {st }}$ Century (IPCC 2001a). Climate change will produce global environmental and socio-economic impacts (IPCC 2001b, USGCRP 2001).

Although fossil fuel power plants and vehicles and cement plants produce $65-92 \%$ of global carbon emissions (IPCC 2001a), deforestation and other land cover changes contribute the remainder. At the same time, deforestation decreases the provision of ecosystem services, including watershed protection, biodiversity conservation, and carbon sequestration.

Forest conservation can restore those ecosystem services, including carbon sequestration. The maximum amount of carbon that global reforestation could sequester amounts to $16-29 \%$ of post-industrial global carbon emissions (IPCC 2001a). In addition, the maximum amount of carbon that forest conservation could prevent from release to the atmosphere amounts to $80-170 \%$ of post-industrial global carbon emissions (IPCC 2001a).

The Voluntary Reporting of Greenhouse Gases Program (U.S. Department of Energy), the Clean Development Mechanism (U.N. Framework Convention on Climate Change), and other policy initiatives are creating nascent markets for forest restoration and conservation projects to sell the rights for sequestered carbon to greenhouse gas producers that want to offset carbon emissions. In order to qualify, a project must project the future carbon baseline: the carbon sequestration or carbon emissions that would likely occur without the project.

We have conducted research in the temperate rainforest of Chile to evaluate three methods for projecting future carbon baseline emissions from conversion of closed natural forest. The objectives of this research are:

1. To quantify future carbon emissions from conversion of closed natural forest in a proposed $570 \mathrm{~km}^{2}$ conservation area around the rural community of Curiñanco.

2. To evaluate the technical aspects, labor cost, and ease of use of the three carbon baseline projection methods that the Nature Conservancy currently uses in its forest carbon projects: extrapolation from Landsat change detection, Geomod, and Forest Restoration Carbon Analysis (FRCA).

This research builds on previous analyses that the U.S. Department of Energy has funded in Chile, including a compilation of forest biomass data (Gayoso and Schlegel 2003) and Landsat analyses and Geomod modeling (Neira et al. 2004).

\section{Methods}

Research Area

The research area is located in southern Chile between $39^{\circ} 27^{\prime} \mathrm{S}$ and $39^{\circ} 51^{\prime} \mathrm{S}$ latitude and between $73^{\circ} 1^{\prime} \mathrm{W}$ and $73^{\circ} 25^{\prime}$ W longitude and comprises the $570 \mathrm{~km}^{2}$ of coastal temperate rainforest (bosque humido templado de la 
cordillera de la costa) that lies between the Pacific Ocean, the Río Cruces, and the shrubland (matorrales) vegetation zone (Figure 1). The Government of Chile Comisión Nacional del Medio Ambiente identified three contiguous priority conservation areas in the zone: Curiñanco, Iñipulli, and Curiñanco-Iñipulli (Lara et al. 2002), named after two local rural communities. We have combined them into one analysis area named after Curiñanco.

In the City of Valdivia, just outside the analysis area, mean annual temperature was $11 \pm 0.5^{\circ} \mathrm{C}$ in the period 1941-1997; mean annual precipitation was $2100 \pm 400 \mathrm{~mm} \mathrm{y}^{-1}$ in the period 1912-2003 (Dirección Meteorológica de Chile, National Oceanic and Atmospheric Administration (USA)). The cool Humboldt Current moderates temperature fluctuations and brings slow, steady rains throughout the year.

Five vegetation types occur in Curiñanco (Marticorena and Rodríguez 1995, CONAF et al. 1999):

1. Closed evergreen forest (bosque siempreverde adulto)

Closed evegreen forest consists of primary closed-canopy vegetation dominated by mesic, broadleaved, forest species, especially Aetoxicon punctatum (olivillo), Drimys winteri (canelo), Eucryphia cordifolia (ulmo), Laurelia philippiana (tepa), Laurelia sempervirens (laurel), Nothofagus dombeyi (coigüe), Persea lingue (lingue), Podocarpus nubigena (mañio de hojas punzantes), Saxegothea conspicua (mañio de hojas cortas), and Weinmannia trichosperma (tineo) (Marticorena and Rodríguez 1995). Forest structure is diverse with at least three stories, emergent individuals, understory ferns, and epiphytes. The Área Protegida Punta Curiñanco. a private $72 \mathrm{~km}^{2}$ reserve in the research area, contains 75 vascular plant species, including 20 shrub species and 17 trees, in closed evergreen forest and other vegetation types (CODEFF 2002). Aetoxicon punctatum has both the highest tree density (323 trees ha-1, $20 \%$ of total density at Punta Curiñanco) and the highest basal area (34 $\mathrm{m}^{2} \mathrm{ha}^{-1}, 58 \%$ of total basal area at Punta Curiñanco). The second most common species is Myrceugenia planiples (pichapicha); the species with the second highest basal area is Laurelia philippiana.

2. Open evergreen forest (renoval de siempreverde)

Open evergreen forest consists of secondary stands of evergreen forest in early to mid-successional recovery after disturbance, including, wind, fire, and timber harvesting. The shade intolerant Drimys winteri (canelo), will often dominate. At Punta Curiñanco, the shrub Embothrium coccineum (notro) has the highest regeneration density with 2340 stems ha-1. $^{-1}$

3. Shrublands (matorrales)

Shrublands consist of short forms of shade intolerant forest species such as Drimys winteri and Eucryphia cordifolia and shrub species such as Embothrium coccineum and Lomatia ferruginea that generally do not exceed a height of $2 \mathrm{~m}$. L. ferruginea shows the strongest regeneration at Punta Curiñanco with 6702 stems ha-1 $^{-1}$ (CODEFF 2002). This vegetation type is separate from a vegetation type just north of the research area that has the same Spanish name (matorrales) by consists of sclerophyllous species of the semi-arid zone.

4. Coastal grasslands (praderas de la Cordillera de la Costa)

These are annual and perennial grasslands that may host shrubs and trees. 


\section{Pinus radiata plantations (plantaciones del pino insigne)}

Pinus radiata (Monterey pine) is native to California. Introduced in 1885 as an ornamental species, the government used it for erosion control in the 1940s and 1950s, and timber companies have since established massive plantations both for wood and paper pulp (Toro and Gessel 1999). Much of the deforestation in temperate rainforest in Chile occurs when timber companies clearcut native forest to replace it with $P$. radiata plantations. Field research has demonstrated that runoff and sedimentation increase after harvest of $P$. radiata plantations near Valdivia (Iroumé et al. 2005) and that nitrogen and phosphorus losses are higher in P. radiata plantations near Valdivia compared to grassland that the plantations replaced.

\section{Forest Inventories}

One member of our team (JG) directed a project funded by the Government of Chile Fondo de Fomento al Desarrollo Científico y Tecnológico (FONDEF) that conducted forest inventories, measured biomass, developed species-specific allometric equations, and determined species-specific carbon fractions and wood densities across the temperate rainforests, shrublands, and grasslands of Chile Administrative Region X (Gayoso et al. 2002, Gayoso and Schlegel 2003). Teams conducted inventories on circular plots of $22.56 \mathrm{~m}$ diameter with nested sub-plots of $5 \times 5 \mathrm{~m}$ squares (dead wood, litter), and $1 \times 1 \mathrm{~m}$ squares (understory). The plots were widely dispersed and representative of the different vegetation types, but not randomly placed. Teams also took soil cores of 0-30 cm depth to measure soil organic carbon. They supplemented this original data with field data taken by the Corporación Nacional Forestal from $500 \mathrm{~m}^{2}$ plots across Chile Administrative Region X (CONAF et al. 1999). The teams analyzed measurements from 1081 circular plots, 103 5-m square plots, 508 1-m square plots, and 88 soil cores. In addition, the project survey previously published biomass research.

\section{Extrapolation from Landsat Change Detection}

On July 23, 1972, the National Aeronautics and Space Administration (NASA) launched the first in a series of moderate-resolution satellites that would later be called Landsat (USGS 2003). Now managed by the U.S. Geological Survey, the program has two satellites in orbit, Landsat 5, launched March 1, 1984, and Landsat 7 , launched April 15, 1999. The Landsat satellites fly in a helio-synchronous orbit at an altitude of $705 \mathrm{~km}$ (USGS 2003). They maintain a constant angle between the Earth and the Sun with an equatorial crossing time of approximately 10:00 AM local time. The orbital period is 99 minutes with the satellites completing a complete orbital cycle of 233 orbits every 16 days, acquiring 248 scenes per orbit across a swath of $185 \mathrm{~km}$. Each sensor captures visible and infrared frequencies in 6 bands at $30 \mathrm{~m}$ resolution. Landsat 5 also captures date in a thermal band of $120 \mathrm{~m}$ resolution. Landsat 7 captures additional data in two thermal bands of $60 \mathrm{~m}$ resolution and one panchromatic band of $15 \mathrm{~m}$ resolution.

Change detection is the analysis of spatial differences from two satellites scenes of acquired over the same 
location at different times. Scientists have used Landsat for detection of land cover change not long after the launch of the first satellite (Howarth and Wickware 1981). Landsat change detection encompasses a wide range of algorithms, including generation of difference images, principal components analysis, spectral mixture analysis, and artificial neural networks (Lu et al. 2004).

We used Landsat images for path 233, row 88 from September 25, 1986 (Landsat 5) and October 23, 1999 (Landsat 7), downloaded at no cost from the NASA-University of Maryland Global Land Cover Facility. The 1986 image is an orthorectified image processed by EarthSat for the NASA GeoCover program. One member of our team (JS) geo-referenced the 1999 image to the 1986 image. He traveled with two other members of our team (EN, PR) to record the land cover at over 100 ground coordinates in order to ground-truth the 1999 Landsat image to the vegetation classes used in the forest inventories. The two team members conducted a maximum likelihood supervised classification of the 1999 and 1986 scenes using ERDAS Imagine raster GIS software. They divided land cover into 13 classes: closed native forest (bosque nativo adulto), open native forest (bosque nativo renoval), forest plantations (plantaciones forestales), shrublands (matorrales), coastal grasslands (praderas), agricultural land (cultivos agrícolas), marshes (humedales), urban areas (areas urbanas), bare ground (terrenos sin vegetación), beaches (playas), waves (olas), snow and glaciers (nieves y glaciares), water (agua). Again, the vegetation classes correspond to the vegetation classes used in the forest inventories. They exported the data layers to ArcGIS software for analysis of plantation areas. Because the spectral characteristics of plantations were similar to closed natural forest, they used Government of Chile surveys (CONAF et al. 1999) to create a separate class for plantations.

Another member of our team (PG) exported the land cover data layers to ENVI/IDL raster GIS software, subset the land cover data layers to a rectangle larger than the Curiñanco analysis area, and combined the 13 land cover classes into three classes:

0. Water in either 1986 or 1999

1. Forest (closed natural forest, open natural forest, plantations)

2. Non-forest (all remaining land cover classes)

Comparison of the forest data layers for 1986 and 1999 produced five classes in a 1986-1999 difference image-the image used the change detection:

0. water

1. non-forest

2. deforestation

3. reforestation

4. forest

Because timber companies use idiosyncratic factors to select areas for future harvest or clearing, we decided to continue our analysis with a different difference image. Because we sought to examine the changes in the most ecologically significant and highest carbon density forests, closed natural forest, we again reclassified the land 
cover images to three classes:

0. Water in either 1986 or 1999

1. Closed natural forest

2. Non-closed natural forest (open natural forest, plantations, and all remaining land cover classes)

We produced a 1986-1999 difference image for detection of change in closed natural forest:

0. water

1. non-closed natural forest

2. loss of closed natural forest

3. gain of closed natural forest

4. closed natural forest

To estimate future change in natural closed forest, we projected into the future only as many years as we possessed observations of the past. Therefore, we projected all of our future carbon baseline estimates for the 13year period 1999-2012. As the most conceptually simple carbon baseline projection method, we extrapolated 2012 natural closed forest area by using the same rate of annual fractional change $\left(y^{-1}\right)$ that we measured for the period 1986-1999. Projected future baseline carbon emissions from loss of closed natural forest equals the product of projected loss of closed natural forest area in the 1999-2012 period and the difference of carbon density of closed natural forest in 1986 and the carbon density of the types of land to which lost closed natural forest was converted in 1999. In this way, extrapolation from Landsat change detection uses the observed rate of change to estimate change in the near future.

\section{Geographic Modeling (Geomod)}

Geomod is a geographic modeling program that uses spatial data of existing land use and land attributes and a user-selected deforestation rate to extrapolate the future locations of different land uses (Pontius et al. 2001). It comes as an MS-DOS command line program or as an extension built into Idrisi GIS software.

Geomod accepts both quantitative data, such as elevation or distance to cities, and qualitative data, such as judgments on soil degradation (e.g. low-medium-high) and administrative boundaries (e.g. province $x$, province y, province z). Using a land use map for one year, Geomod generates what it calls a "suitability" map: "Geomod reclassifies each attribute map such that the grid cells of each category of the attribute map are assigned a percentdisturbed value, obtained by comparing the attribute map to the initial land-use map. The percent-disturbed value of each category in the attribute map is computed as the ratio of the quantity of disturbed grid cells of that category to the quantity of all grid cells of that category...Geomod creates the suitability map by computing for each grid cell a weighted sum of all the reclassified attribute maps" (Pontius et al. 2001).

After the user selects weights for each attribute, Geomod calculates a suitability index for each pixel. Geomod then predicts the land cover of each pixel in a single year based on the modeled "suitability." It then 
compares the modeled land cover to the actual land cover and calculates a statistic: kappa = (percent modeled correctly-calculated expected percent correct due to chance)/(100-calculated expected percent correct due to chance). The user re-runs Geomod trying to obtain higher and higher values of kappa. Once a user decides to accept a result, Geomod can use the "suitability" map and the selected weights to model the land cover of a future year based only on attributes. Geomod correctly classified $85 \%$ of forest and non-forest pixels shown on 1940, 1961, and 1983 forest maps of Costa Rica (Pontius et al. 2001).

Two members of our team (EN, PR) received training in the MS-DOS version of Geomod from Myrna Hall (Geographic Modeling Services, Inc.) in March 2003. They then attempted to run Geomod MS-DOS for the parts of five local administrative units, the Communes of Corral, Lanco, San José de la Mariquina, Máfil, and Valdivia, within the Landsat scene. Geomod MS-DOS either crashed or ran a long time without giving any results. Our team members then tried the Idrisi version of Geomod and, after three weeks, modeled 2012 natural forest cover for the parts of the five communes within the Landsat scene.

They produced and analyzed the following attribute layers:

1. aspect - index number assigned to aspect class (North, East, South, West, flat), calculated from elevation

2. communes - index number assigned to each commune, a local administrative unit

3. elevation - index number assigned to elevation class (0-300 m, 300-600 m, 600-900 m, 900-1200 m, 1200$1500 \mathrm{~m}, 1500-1800 \mathrm{~m}, 1800-2100 \mathrm{~m}, 2400-2775 \mathrm{~m}$ ), $25 \mathrm{~m}$ interval contour lines traced from Instituto Geográfico Militar 1:50 000 scale 1974 maps.

4. potential soil degradation - index number assigned to qualitative classes (intermediate, moderate to high, high, very high, extreme) (Schlatter and Neira 2001)

5. roads - index number assigned to class of distance (0-200 m, 200-400 mm, 400-600 m, 600-800 m, 800-1000 m) from roads and railroads, Instituto Geográfico Militar 1:50 000 scale 1974 maps.

6. slope - index number assigned to slope class (flat, $5^{\circ}-15^{\circ}, 15^{\circ}-30^{\circ}, 30^{\circ}-45^{\circ},>45^{\circ}$ ), calculated from elevation

They assumed a deforestation rate of $0.0309 \mathrm{y}^{1}$, the 1986-1999 rate calculated for the five commune area.

\section{Forest Restoration Carbon Analysis (FRCA)}

FRCA is an integrated spatial analysis of forest inventory, biodiversity, and remote sensing data (Gonzalez et al. 2004). It produces estimates of forest biodiversity and estimates of forest carbon density, spatial data layers of future probabilities of reforestation and deforestation, and a projection of future baseline forest carbon sequestration and emissions for an ecologically-defined area of analysis. FRCA uses principal components analysis, a multivariate statistical test, to calculate the weight of different factors in explaining observed deforestation and reforestation. FRCA employs bivariate statistical fitting of forest change observations to calculate future probabilities of reforestation and deforestation for each pixel in a Landsat image. The factor weights and future probabilities enable FRCA to project future baseline forest carbon sequestration and emissions. 
FRCA proceeds through the following steps:

1. Definition of forest project area based on biological significance

As explained in the methods section 'Research Area,' we selected the Cuniñanco area because it is an area of identifiable ecological unifying characteristics: it is a peninsula between the Pacific Ocean and the Río Cruces; it is an area of continuous coastal temperate rainforest (bosque humido templado de la cordillera de la costa); the Government of Chile has identified is an a priority conservation area that may eventually be managed under one land management plan.

2. Forest inventories

The methods section 'Forest Inventories' describes the identification and measurement of trees in the field (Gayoso et al. 2002).

3. Analyses of primary and secondary forest species patterns.

The forest inventories and Landsat analyses have provided information on the species composition and location of closed (primary) and open (secondary) forest areas.

4. Calculation of biomass using local tree volume equations and species-specific wood densities

The methods section 'Forest Inventories' describes the development of species-specific allometric equations and wood-density values (Table 1).

5. Analyses of forest change from inventories and Landsat

The methods section 'Extrapolation from Landsat Change Detection' details the classification of the Landsat data to land cover classes identified in the forest inventories.

6. Principal components analyses to determine weight of factors in explaining observed deforestation and reforestation

The complex interaction of a multitude of environmental and socio-economic factors determines the amount and spatial pattern of deforestation. Multivariate statistical tests analyze this exact type of situation by linear algebra of matrices of statistical parameters of all possible combinations of a set of independent variables. For example, non-metric multidimensional scaling of ten different environmental and socio-economic variables across the 4 million $\mathrm{km}^{2}$ of the Brazilian legal Amazon indicated that deforestation was most highly correlated to distance to highways and rural population density (Laurence et al. 2002). As another example, principal components analysis of 11 factors across the $18000 \mathrm{~km}^{2}$ Province of Valdivia, the administrative unit that includes the Curiñanco area, suggested that original land cover and the fraction of the population in extreme poverty explained much of the observed variation in deforestation (Vergara and Gayoso 2004).

Principal components analysis (Pearson 1901, Hotelling 1933) offers the exact statistical test required to determine the weight of different quantitative factors in explaining observed patterns of deforestation and reforestation. Principal components analysis determines the factors that account for most of the variability in a set of multivariate data and reveals any clustering of samples. In geometric terms, the PCA algorithm reduces a 
projection of points, representing $n$ samples, in multi-dimensional space into a centered and rotated set of points within $\mathrm{n}$ orthogonal axes, two of which most account for variability in the data, each axis defined by a linear combination of the standardized values of each variable.

One member of the team (PG) examined six factors that could explain patterns of loss of closed natural forest and that were available as raster data. He produced and analyzed the following data layers:

a. non-closed natural forest - meters from each pixel to a non-closed natural forest pixel

b. elevation - meters, NASA Shuttle Radar Topography Mission 2000 data at $90 \mathrm{~m}$ horizontal resolution

C. roads - meters to roads and railways, Instituto Geográfico Militar 1:50 000 scale 1974 maps

d. slope - degrees, calculated by ENVI/IDL from elevation

e. urban areas - meters to pixels classified as urban in 1986 or 1999

f. water - meters to pixels classified as water in 1986 or 1999

He calculated the values of each of the six factors for the $12471230 \times 30 \mathrm{~m}$ pixels that converted from closed natural forest in 1986 to another land cover class in 1999. He conducted principal components analysis on those six data layers in ENV/IDL raster GIS software, using the correlation matrix.

Principal components analysis yields the following:

a. Six principal components, each a spatial data layer equal to a combination of the six original factors

b. Fraction of the variance in the data that each principal component explains.

C. The eigenvalue loadings of each factor for each principal component

d. A $6 \times 6$ matrix of the correlation of each combination of two factors

This provides enough data to calculate the weight of each factor:

$\mathrm{W}_{\mathrm{n}}=\frac{\mathrm{V}_{\mathrm{m}}}{\square_{1}^{\mathrm{i}} \mathrm{V}_{\mathrm{m}}} \frac{\mathrm{L}_{\mathrm{mn}}}{\square_{1}^{\mathrm{q}} \prod_{1}^{\mathrm{j}}\left|\mathrm{L}_{\mathrm{mn}}\right|}$

$\mathrm{n}=$ factors explaining loss of closed natural forest

$\mathrm{j}=$ number of factors

$\mathrm{m}$ = principal components

$\mathrm{i}$ = number of principal components

$q=$ number of explanatory principal components (Cattell 1966)

$\mathrm{W}=$ weight of each factor in explaining observed loss of closed natural forest, range 0-1

$\mathrm{V}=$ fraction of variance explained

$\mathrm{L}=$ eigenvalue loading

7. Deforestation and reforestation probability functions

For each of the six factors we derived an equation of the probability of loss of closed natural forest as a function of the value of the factor. He derived the functions by fitting bivariate curves of the fraction of closed 
natural forest lost from 1986 to 1999 for evenly-spaced classes of values for each factor. The probabilities ranged from 0 to 1 . He also recorded the $95 \%$ upper and lower confidence intervals for the probability functions.

8. Deforestation and reforestation probability for each pixel

Using the spatial data layers for each factor, we calculated the central, high, and low probabilities of loss of closed natural forest of each of the $10196930 \times 30$ m pixels that remained closed natural forest from 1986 to 1999. The sum of the probabilities of the six factors, weighted by the principal component-derived weights, yielded a value for each remaining 1986-1999 closed natural forest pixel of the probability that it would be cleared of forest in the period 1999-2012. The probabilities ranged from 0 to 1.

9. Projection of future baseline deforestation and reforestation

Total projected 1999-2012 loss of natural forest equals the sum of the probabilities of all remaining 19861999 closed natural forest pixels. The threshold probability equals the probability at which the sum of the number of pixels above that probability equals the projected 1999-2012 loss. ENVI/IDL permitted identification of the location of the pixels above the threshold probability.

10. Estimation of carbon storage due to proposed project

Projected future baseline carbon emissions from loss of closed natural forest equals the product of projected loss of closed natural forest area in the period 1999-2012 and the difference of carbon density of closed natural forest in 1986 and the carbon density of the types of land to which lost closed natural forest was converted in 1999. FRCA provides central, high, and low estimates by combining all sources of measurement error from the forest inventories with sources of statistical error from the bivariate probability curves.

\section{Results and Discussion}

\section{Forest Inventories}

Field measurements provided the data to develop allometric equations of aboveground biomass for 16 local species, in addition to allometric equations for 35 species from other sources (Table 1). Closed evergreen forest contains $370 \pm 170$ t ha $^{-1}$ carbon, while the other forest types contain carbon at lower densities amounts (Table 2). Non-native Pinus radiata plantations contain $240 \pm 60$ t ha-1 $^{-1}$ carbon (Table 3). 
Table 1. Allometric equations and wood densities for southern Chile tree species (Gayoso and Schlegel 2003).

\begin{tabular}{|c|c|c|c|c|c|}
\hline species & common name & $\begin{array}{l}\begin{array}{l}\text { volume }\left(\mathrm{cm}^{3}\right), \text { biomass }(\mathrm{kg}) \\
\text { diameter }(\mathrm{cm}), \text { height }(\mathrm{cm})\end{array} \\
\end{array}$ & source & $\begin{array}{r}\text { basic density } \\
\left(\mathrm{kg} \mathrm{m}^{-3}\right)\end{array}$ & source \\
\hline Aextoxicon punctatum & Olivillo & $\ln v=-9.84084+2.19776^{*} \ln d+0.561377^{*} \ln \mathrm{h}$ & Emanuelli 1999 & 0.48798 & field data \\
\hline Amomyrtus luma & Luma & $b=0.263924^{*} d 2.23424$ & field data & & \\
\hline Amomyrtus meli & Meli & $\ln v=-8.994313+2.022983^{*} \ln d+0.474309^{*} \ln h$ & Emanuelli 1999 & & \\
\hline Aristotelia chilensis & Maqui & In $v=-6.85116+1.6647^{*} \ln d$ & Pedrasa 1989 & 0.33100 & Perez 1983 \\
\hline Austrocedrus chilensis & $\begin{array}{l}\text { Ciprés de la } \\
\text { Cordillera }\end{array}$ & $\mathrm{v}=0.000088595^{*}\left(\mathrm{~d}^{\wedge} 2^{*} \mathrm{~h}\right)^{\wedge} 0.903631$ & Loguercio 1997 & 0.42400 & Perez 1983 \\
\hline Azara dentata & Corcolén & $\mathrm{v}=\mathrm{e}^{\wedge}\left(-8.91055+2.28335^{\star} \ln \mathrm{d}\right)$ & Donoso 1988 & 0.47435 & G. avellana \\
\hline Azara integrifolia & & $v=e^{\wedge}\left(-8.91055+2.28335^{\star} \ln d\right.$ & Donoso 1988 & 0.47435 & G. avellana \\
\hline Blepharocalyx cruckshanksii & Temu & $\mathrm{v}=0.0381+0.4731^{*}(\mathrm{~d} / 100) 2^{*}\left(-5.081+0.7704^{*} \mathrm{~h}\right)$ & Corvalán 1987 & & \\
\hline Caldcluvia paniculata & Tiaca & $\mathrm{v}=0.170179+3.1379^{*} \mathrm{~d}^{\wedge} 2^{*} \mathrm{~h} / 100000$ & Urzúa et al. 1980 & 0.55500 & Perez 1983 \\
\hline Citronella mucronata & $\begin{array}{l}\text { Huillipatagua, } \\
\text { Naranjillo }\end{array}$ & $v=e^{\wedge}\left(-8.91055+2.28335^{\star} \ln d\right)$ & Donoso 1988 & & \\
\hline Cordia decandra & \begin{tabular}{|l|} 
Carbonillo \\
\end{tabular} & $\ln v=-6.85116+1.6647^{*} \ln d$ & Pedrasa 1989 & 0.43579 & D. winteri \\
\hline Crinodendron hookerianum & \begin{tabular}{|l|l|l} 
Polizón \\
\end{tabular} & $\mathrm{v}=\mathrm{e}^{\wedge}\left(-8.91055+2.28335^{\star} \ln \mathrm{d}\right)$ & \begin{tabular}{|l|l|} 
Donoso 1988 \\
\end{tabular} & 0.43579 & D. winteri \\
\hline Dasyphyllum diacanthoides & Trevo & $\ln b=-1.835+2.291 * \ln d$ & \begin{tabular}{|l|l|l} 
field data \\
\end{tabular} & & \\
\hline Drimys winteri & Canelo & $\mathrm{b}=0.205204^{*} \mathrm{~d}^{\wedge} 2.16616$ & field data & & \\
\hline Embothrium coccineum & Notro & $\mathrm{v}=0.000028^{*} \mathrm{~d}^{\wedge} 2^{*} \mathrm{~h}$ & Emanuelli 1999 & 0.47435 & field data \\
\hline Escallonia revoluta & Madroño & In $v=-6.85116+1.6647^{*} \ln d$ & Pedrasa 1989 & 0.71000 & Perez 1983 \\
\hline Eucryphia cordifolia & Ulmo & $b=0.218583^{*} d^{\wedge} 2.24614$ & field data & & \\
\hline Fitzroya cupressoides & Alerce & $\begin{array}{l}v=\left(3.8^{*} 10^{\wedge}-5^{\star} d^{\wedge} 2^{*} h\right)-\left(\left(6.55^{\star} 10^{\wedge}-\right.\right. \\
\left.10)^{*}\left(d^{\wedge} 2^{\star} h\right)^{\wedge} 2\right)+\left(7.2^{*} 10^{\wedge}(-15)^{*}\left(d^{\wedge} 2^{*} h\right)^{\wedge} 3\right)\end{array}$ & Emanuelli 1999 & 0.40500 & Perez 1983 \\
\hline Fuchsia magellanica & Chilco & $v=e^{\wedge}\left(-8.91055+2.28335^{*} \ln d\right)$ & Donoso 1988 & 0.71000 & Perez 1983 \\
\hline Gevuina avellana & Avellano & $b=0.209634^{*} d^{\wedge} 2.13023$ & field data & 0.47435 & field data \\
\hline Laurelia philippiana & Tepa & $b=\left(-1.62368+0.665237^{\star} d\right)^{\wedge} 2$ & field data & & \\
\hline Laurelia sempervirens & Laurel & $v=0.008221+\left({ }^{*} d^{\wedge} 2^{*} h\right.$ & Gantz 1994 & 0.41369 & field data \\
\hline Lomatia dentata & Avellanillo & $v=e^{\wedge}\left(-8.91055+2.28335^{*} \ln d\right)$ & Donoso 1988 & 0.47435 & G. avellana \\
\hline Lomatia ferruginea & Fuinque & $v=e^{\wedge}\left(-8.91055+2.28335^{*} \ln d\right)$ & Donoso 1988 & 0.47435 & G. avellana \\
\hline Lomatia hirsuta & Radal & $v=0.007019+0.00002229^{*} d^{\wedge} 3$ & \begin{tabular}{|l|l|} 
Corti 1996 \\
\end{tabular} & 0.47435 & G. avellana \\
\hline Luma apiculata & Arrayán & $v=0.0381+0.4731^{*}(d / 100) 2^{*}\left(-5.081+0.7704^{*} h\right)$ & Corvalán 1987 & & \\
\hline Maytenus boaria & Maitén & $v=e^{\wedge}\left(-8.91055+2.28335^{*} \ln d\right)$ & Donoso 1988 & 0.47435 & G. avellana \\
\hline Maytenus magellanica & Leña dura & $\mathrm{v}=0.0381+0.4731^{*}(\mathrm{~d} / 100) 2^{*}\left(-5.081+0.7704^{*} \mathrm{~h}\right)$ & Corvalán 1987 & & \\
\hline Myrceugenia correifolia & Petrillo & $v=0.0381+0.4731^{*}(d / 100) 2^{*}\left(-5.081+0.7704^{*} h\right)$ & Corvalán 1987 & & \\
\hline Myrceugenia exsucca & Pitra & $\mathrm{v}=0.0381+0.4731^{*}(\mathrm{~d} / 100) 2^{*}\left(-5.081+0.7704^{*} \mathrm{~h}\right)$ & Corvalán 1987 & & \\
\hline Myrceugenia planiples & $\begin{array}{l}\text { Picha-picha, } \\
\text { Patagua }\end{array}$ & $v=0.0381+0.4731^{*}(d / 100) 2^{*}\left(-5.081+0.7704^{*} h\right)$ & Corvalán 1987 & & \\
\hline Nothofagus alpina & Raulí & $b=0.175074^{*} d^{\wedge} 2.30232$ & field data & & \\
\hline Nothofagus antarctica & Nirre & $\begin{array}{l}\mathrm{v}=0.59330761 / 10000^{*} \mathrm{~d}^{\wedge}(2.16326966)^{*} \mathrm{~h}^{\wedge}(0.681722 \\
48)\end{array}$ & $\begin{array}{l}\text { Gayoso et al. } \\
2002\end{array}$ & 0.46400 & Perez 1983 \\
\hline Nothofagus betuloides & $\begin{array}{l}\text { Coigüe de } \\
\text { Magallanes }\end{array}$ & $\ln b=-1.68+2.15 \ln d$ & Magni 1995 & & \\
\hline Nothofagus dombeyi & Coigüe & $\mathrm{b}=0.150381^{*} \mathrm{~d}^{\wedge} 2.32103$ & field data & & \\
\hline Nothofagus nitida & Coihue de Chiloé & $\mathrm{b}=0.391757^{\star} \mathrm{d}^{\wedge} 2.10526$ & field data & & \\
\hline Nothofagus obliqua & Roble & $b=0.142233^{*} d^{\wedge} 2.37985$ & field data & & \\
\hline Nothofagus pumilio & Lenga & $\ln b=-2.21+1.96 \ln d+0.52 \ln h$ & \begin{tabular}{|l|l|} 
Valenzuela 1995 \\
\end{tabular} & & \\
\hline Ovidia pillo-pillo & Pillo-Pillo & In v $=-6.85116+1.6647^{*} \ln d$ & Donoso 1988 & 0.33100 & Perez 1983 \\
\hline Persea lingue & \begin{tabular}{|l}
$\begin{array}{l}\text { Lingue-Tepa- } \\
\text { Laurel }\end{array}$ \\
\end{tabular} & $\mathrm{b}=0.107738^{\star} \mathrm{d}^{\wedge} 2.38348$ & field data & & \\
\hline Peumus boldus & Boldo & $\ln v=-2.3523+0.1866 \ln d+0.7952 \ln d^{\wedge} 2^{*} h$ & \begin{tabular}{|l|l|} 
Toral et al. 1988 \\
\end{tabular} & & \\
\hline Pilgerodendron uviferum & \begin{tabular}{|l|} 
Alerce, Canelo y \\
Cipres de las \\
Guaitecas \\
\end{tabular} & $\ln v=-10.12171+0.9610084^{*} \ln \left(\mathrm{d}^{\wedge} 2^{*} \mathrm{~h}\right)$ & $\begin{array}{l}\text { Gayoso et al } \\
2002\end{array}$ & 0.40500 & $\begin{array}{l}\text { Fitzroya } \\
\text { cupressoides }\end{array}$ \\
\hline Podocarpus nubigena & $\begin{array}{l}\text { Mañío de hojas } \\
\text { punzantes, Mañio } \\
\text { Macho } \\
\end{array}$ & $b=0.146773^{*} d^{\wedge} 2.31135$ & field data & & \\
\hline Podocarpus saligna & $\begin{array}{l}\text { Mañío de hojas } \\
\text { largas }\end{array}$ & $b=0.146773^{\star} d^{\wedge} 2.31135$ & field data & & \\
\hline Prumnopitys andina & Lleuque & $\mathrm{b}=0.292754^{*} \mathrm{~d}^{\wedge} 2.06925$ & field data & & \\
\hline Pseudopanax laetevirens & Sauco & $\ln \mathrm{b}=-1.835+2.291^{*} \ln \mathrm{d}$ & field data & & \\
\hline Rhaphithamnus spinosus & Arrayán macho & $v=e^{\wedge}\left(-8.91055+2.28335^{*} \ln d\right)$ & \begin{tabular}{|l|l|} 
Donoso 1988 \\
\end{tabular} & 0.43579 & D. winteri \\
\hline Saxegothaea conspicua & Mañio Hembra & $b=0.292754^{*} d^{\wedge} 2.06925$ & field data & & \\
\hline Sophora microphylla & Pelu & $\mathrm{v}=\mathrm{e}^{\wedge}\left(-8.91055+2.28335^{\star} \ln \mathrm{d}\right)$ & Donoso 1988 & 0.48798 & A. punctatum \\
\hline Tepualia stipularis & Tepu & $\mathrm{v}=0.0381+0.4731^{*}(\mathrm{~d} / 100) 2^{*}\left(-5.081+0.7704^{*} \mathrm{~h}\right)$ & Corvalán 1987 & & \\
\hline Weinmannia trichosperma & \begin{tabular}{|l} 
Tineo, Palo santo \\
\end{tabular} & $b=0.105181^{*} d^{\wedge} 2.41804$ & field data & & \\
\hline
\end{tabular}


Table 2. Carbon density of natural temperate rainforest vegetation (Gayoso and Schlegel 2003) and Pinus radiata plantations (Rodríguez et al. 2003, Gayoso and Schlegel 2003, Gayoso et al. 2002) (see Table 3), Chile.

\begin{tabular}{|c|c|c|c|c|c|}
\hline vegetation type & & component & $\begin{array}{r}\text { inventory } \\
\text { plots }\end{array}$ & $\begin{array}{r}\text { carbon } \\
\text { t ha-1 }^{-1}\end{array}$ & $\begin{array}{r}\text { std. dev. } \\
\text { tha-1 }\end{array}$ \\
\hline \multicolumn{6}{|l|}{ components } \\
\hline closed evergreen forest & bosque siempreverde adulto & aboveground & 177 & 140 & 88 \\
\hline closed evergreen forest & bosque siempreverde adulto & roots & 177 & 20 & 32 \\
\hline open evergreen forest & renoval de siempreverde & aboveground & 43 & 100 & 83 \\
\hline open evergreen forest & renoval de siempreverde & roots & 43 & 18 & 23 \\
\hline Chile temperate coastal rainforest & bosque humido templado & understory & 448 & 3 & 3 \\
\hline Chile temperate coastal rainforest & bosque humido templado & leaves & 310 & 8 & 3 \\
\hline Chile temperate coastal rainforest & bosque humido templado & dead wood & 103 & 44 & 29 \\
\hline Chile temperate coastal rainforest & bosque humido templado & soil $(0-30 \mathrm{~cm})$ & 82 & 150 & 12 \\
\hline shrublands & matorrales & aboveground & 18 & 8 & 4 \\
\hline shrublands & matorrales & fine roots (A horizon) & 12 & 34 & 12 \\
\hline shrublands & matorrales & fine roots (B horizon) & 12 & 14 & 5 \\
\hline shrublands & matorrales & soil (A horizon) & 18 & 100 & 24 \\
\hline shrublands & matorrales & soil (B horizon) & 18 & 64 & 12 \\
\hline coastal grasslands & praderas de la Cordillera de la Costa & aboveground & 20 & 4 & 1 \\
\hline coastal grasslands & praderas de la Cordillera de la Costa & fine roots (A horizon) & 20 & 4 & 3 \\
\hline coastal grasslands & praderas de la Cordillera de la Costa & fine roots (B horizon) & 20 & 1 & 1 \\
\hline coastal grasslands & praderas de la Cordillera de la Costa & soil (A horizon) & 20 & 110 & 21 \\
\hline $\begin{array}{l}\text { coastal grasslands } \\
\text { totals }\end{array}$ & praderas de la Cordillera de la Costa & soil (B horizon) & 20 & 56 & 23 \\
\hline closed evergreen forest & bosque siempreverde adulto & total & & 370 & 170 \\
\hline open evergreen forest & renoval de siempreverde & total & & 330 & 150 \\
\hline Pinus radiata plantations & plantaciones del pino insigne & total & & 240 & 60 \\
\hline shrublands & matorrales & total & & 220 & 60 \\
\hline coastal grasslands & praderas de la Cordillera de la Costa & total & & 170 & 50 \\
\hline
\end{tabular}

Table 3. Carbon density of 16-year Pinus radiata plantations in southern Chile (Rodríguez et al. 2003, Gayoso and Schlegel 2003, Gayoso et al. 2002). Because companies continue to thin plantations and harvest on a 20-30 year rotation (Toro and Gessel 1999), this estimate for a 16-year plantation gives the approximate average carbon density over time.

\begin{tabular}{|c|c|c|c|c|c|c|c|c|}
\hline \multirow[b]{2}{*}{ component } & \multicolumn{3}{|c|}{ Rodríguez et al. 2003} & \multicolumn{3}{|c|}{ Gayoso et al. 2002} & \multirow[b]{2}{*}{$\begin{array}{c}\text { carbon } \\
\mathrm{kg}^{2} \text { tree- }\end{array}$} & \multirow[b]{2}{*}{$\begin{array}{l}\text { std. dev. } \\
\mathrm{kg} \text { tree-1 }\end{array}$} \\
\hline & $\begin{array}{l}\text { biomass } \\
\mathrm{kg} \text { tree }^{-1}\end{array}$ & $\begin{array}{l}\text { std. dev. } \\
\mathrm{kg} \text { tree-1 }\end{array}$ & $\begin{array}{r}\text { sample } \\
\text { trees }\end{array}$ & $\begin{array}{r}\text { carbon fraction } \\
\text { of biomass }\end{array}$ & $\begin{array}{l}\text { standard } \\
\text { deviation }\end{array}$ & \begin{tabular}{r|} 
sample \\
$\mathrm{n}$
\end{tabular} & & \\
\hline needles & 36 & 29 & 36 & 0.450 & 0.035 & 39 & 16 & \\
\hline anches & 73 & 34 & 36 & 0.452 & 0.027 & 39 & 33 & \\
\hline stem & 220 & 129 & 36 & 0.454 & 0.014 & 46 & 100 & \\
\hline park & 26 & 13 & 36 & 0.453 & 0.028 & 31 & 12 & \\
\hline roots & 19 & 1 & 36 & 0.450 & 0.012 & 22 & 9 & \\
\hline total biomass & 370 & 160 & & & & & 170 & \\
\hline
\end{tabular}

\begin{tabular}{lr}
\hline tree density (Rodriguez et al. 2003) & 489 trees ha- $^{-1}$ \\
biomass carbon density & $80 \pm 46 \mathrm{t} \mathrm{ha}^{-1}$ \\
soil carbon (Gayoso and Schlegel 2003) & $150 \pm 12 \mathrm{t} \mathrm{ha}^{-1}$ \\
total carbon density & $240 \pm 60 \mathrm{t} \mathrm{ha}^{-1}$ \\
\hline
\end{tabular}

\section{Extrapolation from Landsat Change Detection}

Closed natural forest covered the largest surface area in both 1986 and 1999 (Table 4, Figure 2). From 1986 to 1999 , the area experienced net deforestation of $1900 \mathrm{ha}$, proceeding at a rate of $0.0003 \mathrm{y}^{-1}$ (Table 5, Figure 3).

Gross deforestation was 6900 ha (Table 5). Gross loss of closed natural forest was 8800 ha, proceeding at a rate of $0.042 \mathrm{y}^{-1}$ (Table 6, Figure 4). 
Figure 1.

\section{Curiñanco, Chile}

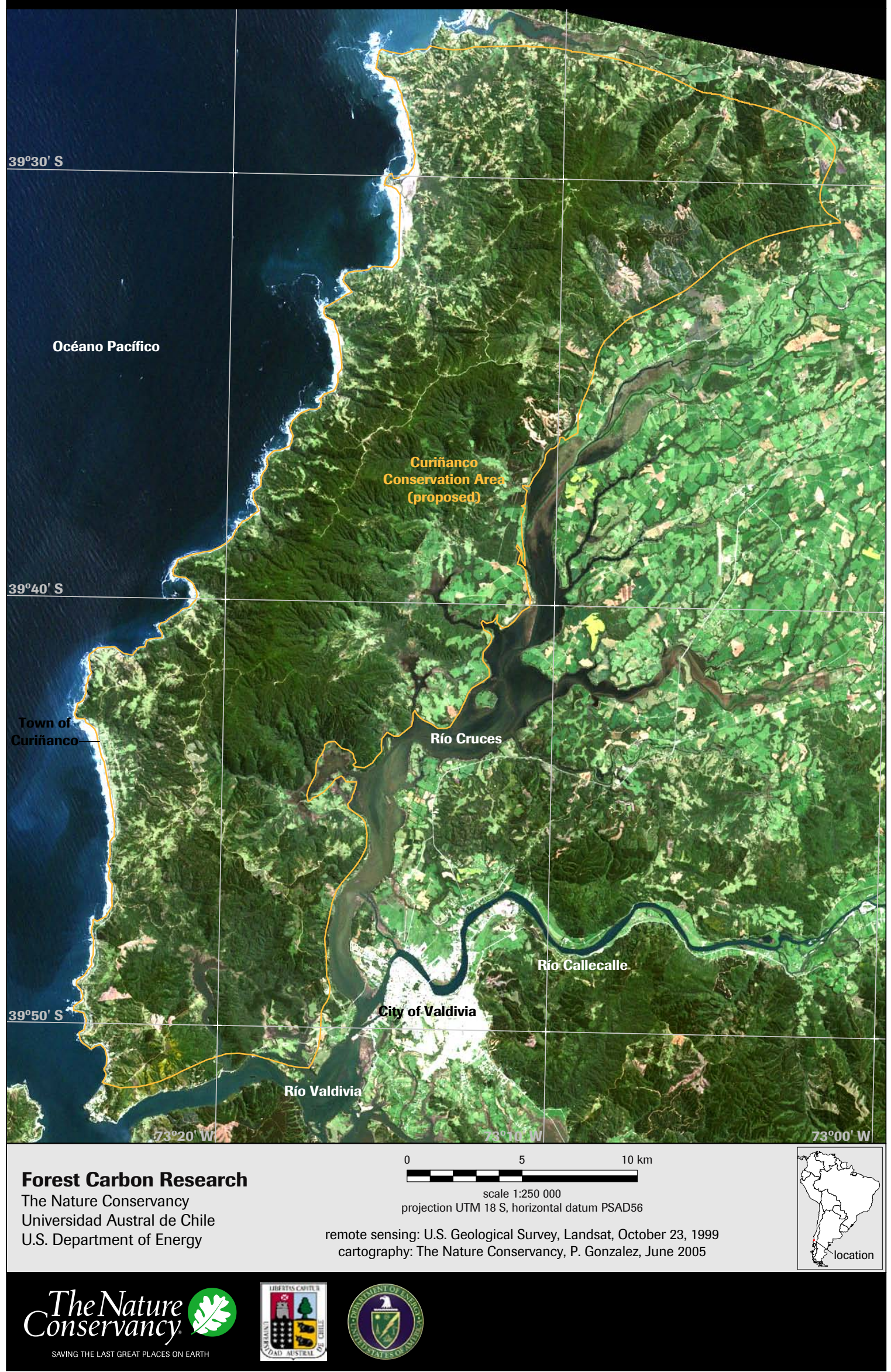


Figure 2.

\section{Curiñanco, Chile}

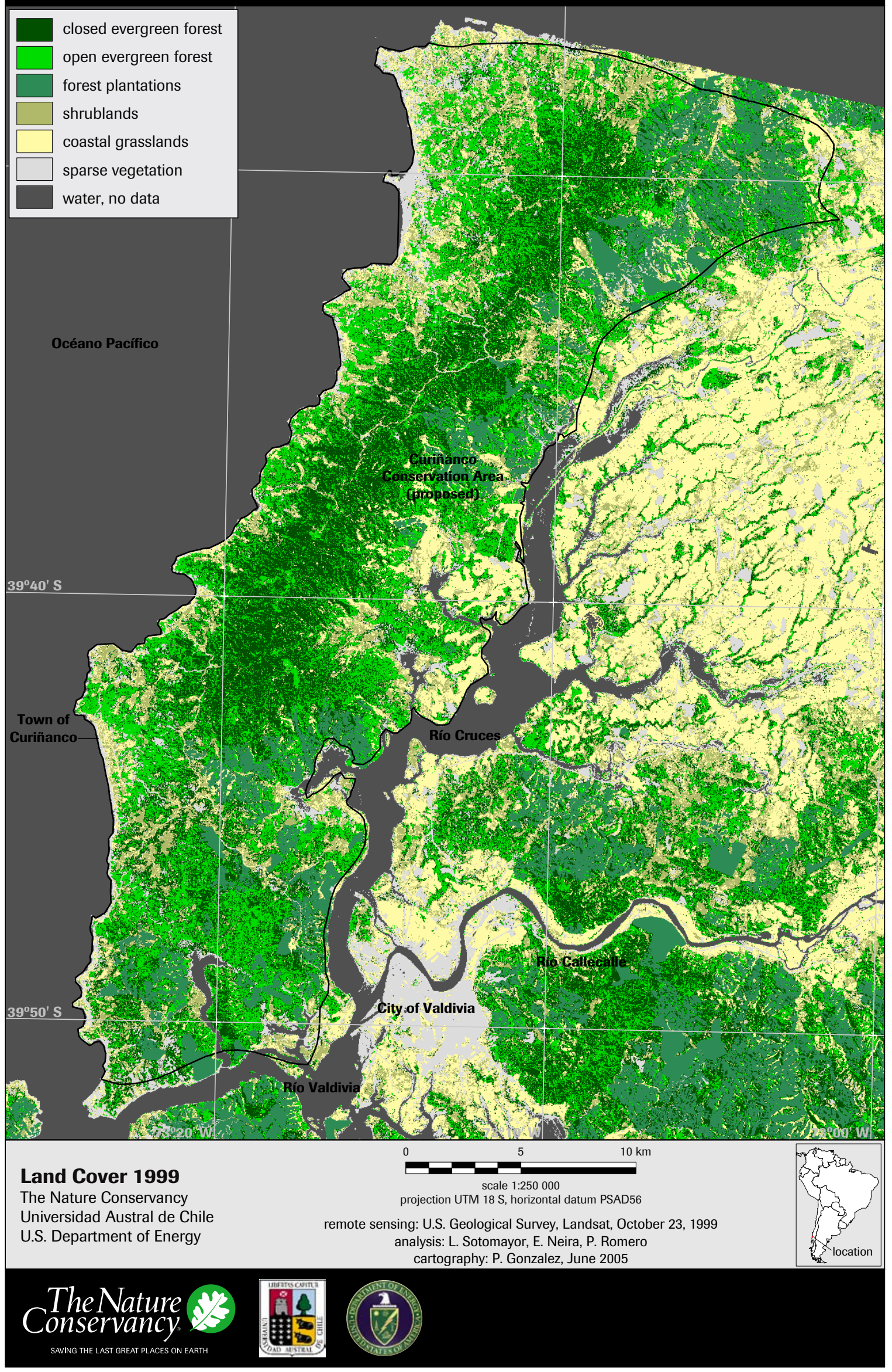


Figure 3.

\section{Curiñanco, Chile}

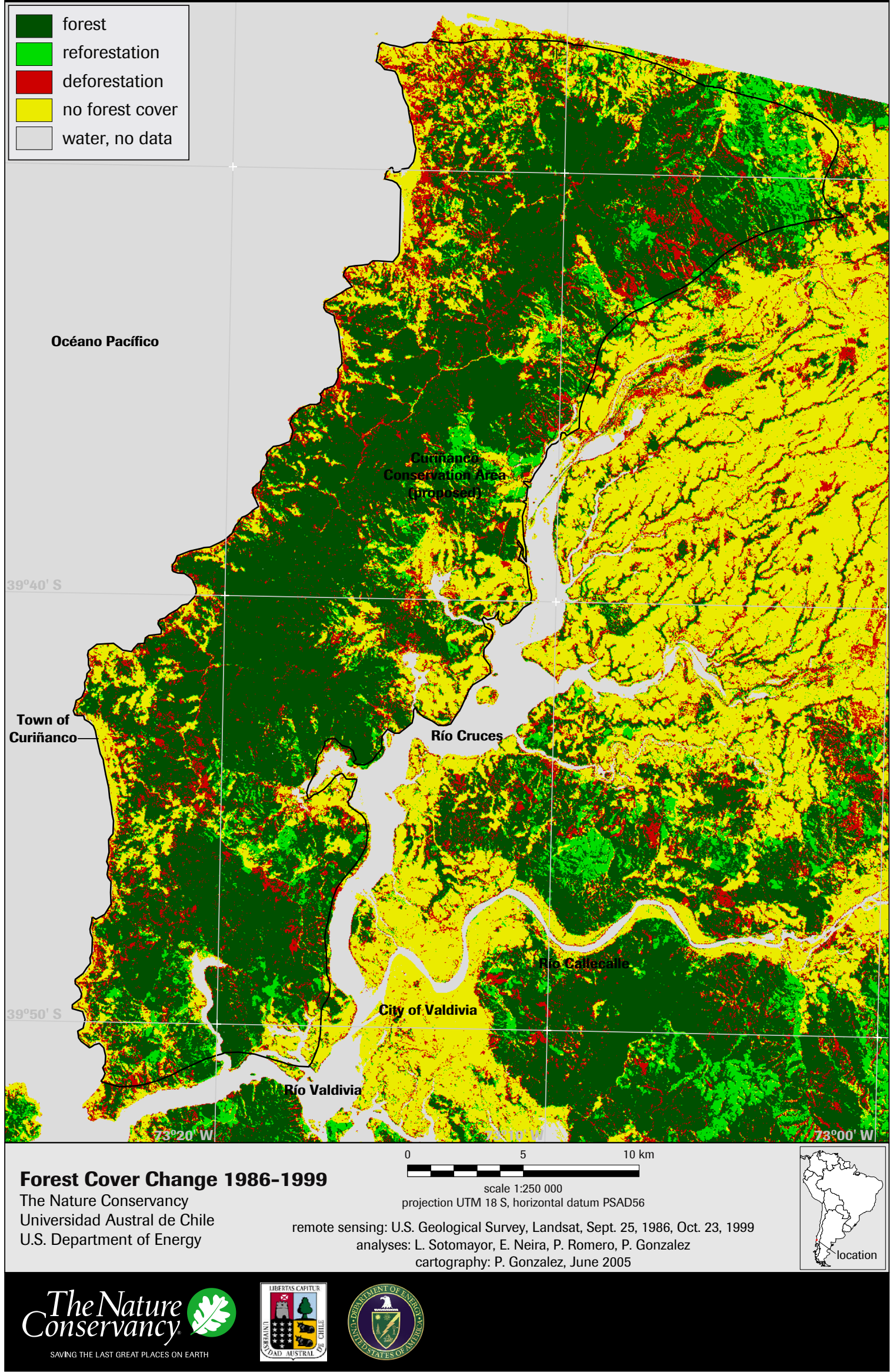


Figure 4.

\section{Curiñanco, Chile}

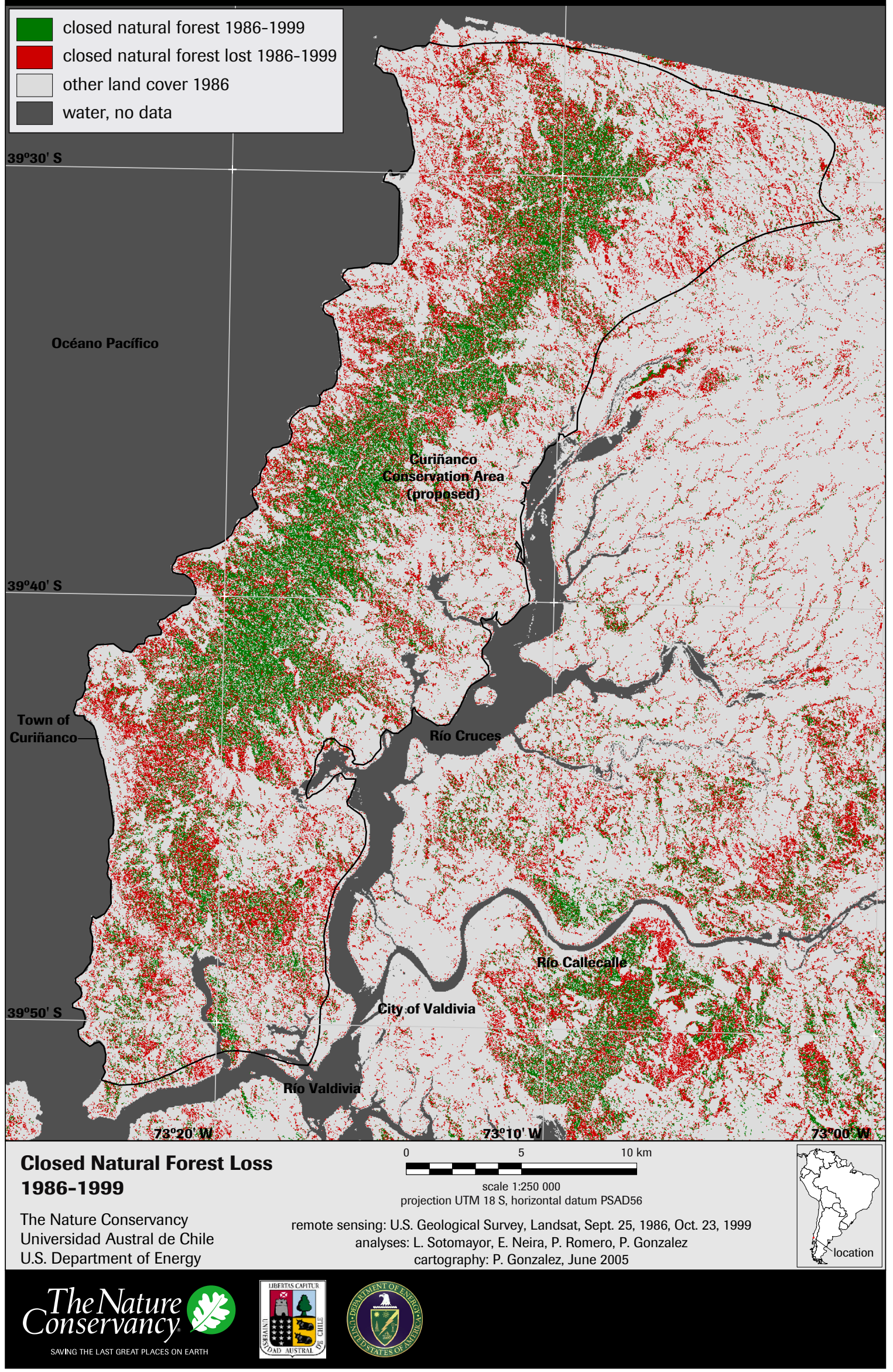


The 1986-1999 conversion of closed evergreen forest to open evergreen forest, Pinus radiata plantations, shrublands, grasslands, and sparse vegetation decreased the carbon density on those lands from $370 \pm$ $170 \mathrm{t} \mathrm{ha}^{-1}$ carbon to an average of $100 \mathrm{t} \mathrm{ha}^{-1}$ (maximum $160 \mathrm{t} \mathrm{ha}^{-1}$, minimum $50 \mathrm{t} \mathrm{ha}^{-1}$ ) (Table 7). Consequently, the conversion released 1.1 million $\mathrm{t}$ carbon.

Linear extrapolation of the rate of closed natural forest loss of $0.042 \mathrm{y}^{-1}$ indicated a reduction of the 19861999 remaining closed natural forest by another 5000 ha in the period 1999-2012, releasing another $520000 \mathrm{t}$ carbon. These are the projected baseline carbon emissions from loss of closed natural forest that a forest conservation project could prevent.

Table 4. Land cover, 1986-1999, Curiñanco, Chile, from Landsat analysis.

\begin{tabular}{|c|c|c|c|c|c|}
\hline & $\begin{array}{r}1986 \\
\text { ha }\end{array}$ & $\begin{array}{r}1999 \\
\text { ha }\end{array}$ & $\begin{array}{r}\text { net change } \\
1986-1999 \\
\text { ha }\end{array}$ & $\begin{array}{r}\text { net change } \\
1986-1999 \\
\text { ha }^{-1}\end{array}$ & $\begin{array}{r}\text { net change } \\
1986-1999\end{array}$ \\
\hline \multicolumn{6}{|l|}{ forests } \\
\hline closed natural forest & 20000 & 18000 & -2800 & -210 & -0.0009 \\
\hline open natural forest & 18000 & 16000 & -2100 & -160 & -0.0008 \\
\hline forest plantations & 3400 & 6400 & 3000 & 230 & 0.0061 \\
\hline total forest & 42000 & 40000 & -1900 & -150 & -0.0003 \\
\hline \multicolumn{6}{|l|}{ non-forest land } \\
\hline shrublands & 6100 & 6400 & 300 & 30 & 0.0004 \\
\hline coastal grasslands & 7300 & 6300 & -1000 & -70 & -0.0009 \\
\hline sparse vegetation & 1300 & 3900 & 2600 & 200 & 0.0132 \\
\hline total non-forest land & 15000 & 17000 & 1900 & 150 & 0.0009 \\
\hline total land & 56000 & 56000 & 0 & 0 & 0 \\
\hline water & 900 & 900 & 0 & 0 & 0 \\
\hline total analysis area & 57000 & 57000 & 0 & 0 & 0 \\
\hline
\end{tabular}

Table 5. Gross changes in total forest area, 1986-1999, Curiñanco, Chile, from Landsat analysis.

\begin{tabular}{lrrrr}
\hline & $\begin{array}{r}1986 \\
\text { initial condition } \\
\text { forest change }\end{array}$ & $\begin{array}{r}1986-1999 \\
\text { hross change }\end{array}$ & $\begin{array}{r}1986-1999 \\
\text { gross change } \\
\text { ha } \text { y }^{-1}\end{array}$ & $\begin{array}{r}\text { 1986-1999 } \\
\text { gross change }\end{array}$ \\
\hline no forest & & 9700 & & y $^{-1}$ \\
deforestation & forest 42000 & 6900 & 530 & 0.013 \\
reforestation & non-forest 15 1500 & 5000 & 380 & 0.026 \\
forest & & 35000 & & \\
total land & & $\mathbf{5 6 0 0 0}$ & & \\
\hline
\end{tabular}

Table 6. Gross changes in closed natural forest area, 1986-1999, Curiñanco, Chile, from Landsat analysis.

\begin{tabular}{|c|c|c|c|c|}
\hline $\begin{array}{l}\text { change in } \\
\text { closed natural forest }\end{array}$ & $\begin{array}{r}1986 \\
\text { initial condition } \\
\text { ha }\end{array}$ & $\begin{array}{r}1986-1999 \\
\text { gross change } \\
\text { ha }\end{array}$ & $\begin{array}{r}1986-1999 \\
\text { gross change } \\
\text { ha y }^{-1}\end{array}$ & $\begin{array}{r}1986-1999 \\
\text { gross change } \\
\mathrm{y}^{-1}\end{array}$ \\
\hline no closed natural forest & & 27000 & & \\
\hline natural forest loss & closed natural forest 20000 & 11200 & 860 & 0.042 \\
\hline natural forest increase & non-closed natural forest 36000 & 8500 & 650 & 0.018 \\
\hline closed natural forest & & 9200 & & \\
\hline total land & & 56000 & & \\
\hline
\end{tabular}


Table 7. Forest carbon loss from conversion of closed natural forest, from forest inventories and Landsat.

\begin{tabular}{|c|c|c|c|c|c|c|c|c|c|}
\hline \multirow[b]{2}{*}{ vegetation type } & \multirow{2}{*}{$\begin{array}{r}\text { fraction of 1986-1999 } \\
\text { loss of closed } \\
\text { evergreen forest }\end{array}$} & \multicolumn{2}{|c|}{$\begin{array}{l}\text { carbon standard } \\
\text { density deviation }\end{array}$} & \multicolumn{3}{|c|}{$\begin{array}{c}\text { difference from } \\
\text { closed evergreen forest }\left(t \mathrm{th}^{-1}\right)\end{array}$} & \multicolumn{3}{|c|}{$\begin{array}{c}\text { difference weighted } \\
\text { by } 1986-1999 \text { loss }\left(\mathrm{t} \mathrm{ha}^{-1}\right)\end{array}$} \\
\hline & & $\mathrm{tha}^{-1}$ & tha-1 & central & high & low & central & high & low \\
\hline closed evergreen forest & 1.00 & 370 & 170 & & & & & & \\
\hline open evergreen forest & 0.64 & 330 & 150 & 40 & 50 & 30 & 25 & 34 & 17 \\
\hline forest plantations & 0.13 & 240 & 58 & 130 & 240 & 30 & 17 & 31 & \\
\hline shrublands & 0.08 & 220 & 60 & 150 & 260 & 40 & 12 & 21 & \\
\hline coastal grasslands & 0.06 & 170 & 50 & 200 & 320 & 80 & 12 & 19 & \\
\hline sparse vegeation & 0.10 & 0 & 0 & 370 & 540 & 200 & 36 & 53 & 19 \\
\hline total conversion & 1.00 & & & 890 & 1500 & 330 & 100 & 160 & 50 \\
\hline
\end{tabular}

\section{Geographic Modeling (Geomod)}

Iterative trials of Geomod-Idrisi produced a set of attribute weights that produced a Kappa value of 0.89 . Geomod-Idrisi produced a map of projected natural forest in 2012 (Figure 5). Modeled 1999-2012 loss of closed natural forest in the Curiñanco analysis area was 2500 ha and $250000 \mathrm{t}$.

Figure 5. Natural forest 2012, projected by Geomod (cartography E. Neira).

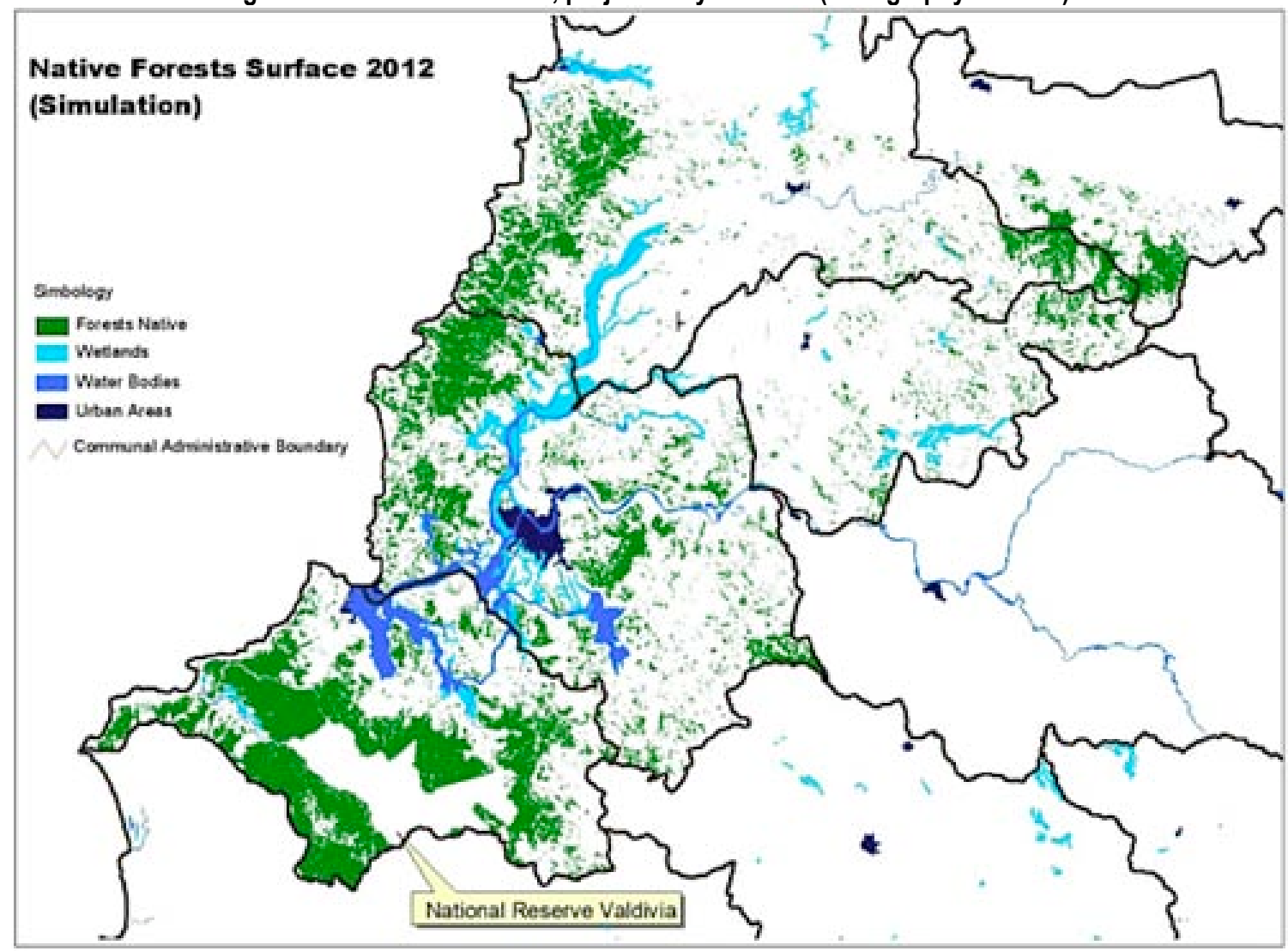


Forest Restoration Carbon Analysis (FRCA)

The results sections 'Forest Inventories' and 'Extrapolation from Landsat Change Detection' provide the results for FRCA steps 1-5. Building on those previous steps, principal components analysis yielded the fraction of variance explained and the eigenvalue loadings. These data revealed that distance to urban area explained more of the observed loss of closed natural forest than the other factors (Table 8). The observed patterns of loss of closed natural forest closely fit polynomial probability functions for each factor (Table 9, Figure 6).

The total probability distribution exhibited a Gaussian form (Figure 7) with probabilities ranging from 0.34 ( $\max .0 .36$, min. 0.31) to 0.68 ( $\max .0 .69$, min. 0.68) and a threshold probability of 0.508 (max. 0.515, min. 0.501). Probabilities were elevated close to the towns on the coast and river (Figure 8), leading to a projected 2012 loss of closed natural forest in those areas (Figure 9). FRCA projected a loss of $4700 \pm 100$ ha and $480000 \mathrm{t}$ (maximum $760000 \mathrm{t}$, minimum $220000 \mathrm{t}$ ), proceeding at a rate of $0.039 \pm 0.001 \mathrm{y}^{1}$.

Table 8. Weight of deforestation factors, derived from principal components analysis of $12471230 \times 30 \mathrm{~m}$ pixels and six deforestation factors.

\begin{tabular}{lcc}
\hline factor & weight rank \\
\hline distance to non-closed natural forest & 0.152 & 6 \\
elevation & 0.165 & 3 \\
distance to roads & 0.164 & 4 \\
slope & 0.159 & 5 \\
distance to urban area & 0.186 & 1 \\
distance to water & 0.174 & 2 \\
\hline
\end{tabular}

Table 9. Probability functions of loss of closed natural forest $(y)$ for six factors $(x)$ (See Figure 6).

\begin{tabular}{|c|c|c|c|c|c|c|}
\hline factor & $\begin{array}{r}\text { distance from } \\
\text { non-closed } \\
\text { natural forest } \\
\end{array}$ & elevation & $\begin{array}{r}\text { distance from } \\
\text { roads }\end{array}$ & slope & $\begin{array}{r}\text { distance from } \\
\text { urban area } \\
\end{array}$ & $\begin{array}{r}\text { distance from } \\
\text { water }\end{array}$ \\
\hline units & $\mathrm{m}$ & $\mathrm{m}$ & $\mathrm{m}$ & degrees & $\mathrm{m}$ & $\bar{m}$ \\
\hline equation & & $\begin{array}{l}y=a+b x^{2} \\
+c x^{4}+d x^{6}\end{array}$ & $\begin{array}{r}y=a+b x \\
+c x^{2}+d x^{2.5}\end{array}$ & $\begin{array}{r}y=a+b x \\
+c x^{2}+d x^{3}\end{array}$ & $\begin{array}{r}y=a+b x \\
+c x^{2}+d x^{3}\end{array}$ & $\begin{array}{r}y=a+b x \\
+c x^{1.5}+d x^{2.5}\end{array}$ \\
\hline & $y=a+b \ln x$ & $+e x^{8}$ & $+e x^{3}$ & $+\mathrm{ex}^{0.5}$ & $+e x^{4}$ & $+\mathrm{ex}^{0.5}$ \\
\hline \multicolumn{7}{|c|}{ coefficients } \\
\hline a & 1.394184095 & 0.754621718 & 0.621565345 & 0.963597694 & 0.659622954 & 1.00191973 \\
\hline b & -0.247725322 & $-1.60851 \mathrm{E}-06$ & -0.000152306 & 0.087366719 & $-9.34146 \mathrm{E}-05$ & 0.001999882 \\
\hline c & & $-1.27703 \mathrm{E}-11$ & $2.60481 \mathrm{E}-07$ & -0.002138699 & $2.78765 \mathrm{E}-08$ & $-3.33418 \mathrm{E}-05$ \\
\hline$d$ & & $6.73687 \mathrm{E}-17$ & $-6.43741 \mathrm{E}-09$ & 2.73773E-05 & $-7.57889 \mathrm{E}-12$ & 2.67878E-09 \\
\hline e & & $-7.98194 \mathrm{E}-23$ & 4.35921E-11 & -0.347771314 & 7.30684E-16 & -0.044757107 \\
\hline$r^{2}$ & 0.9999 & 0.9910 & 0.9588 & 0.9802 & 0.9264 & 0.9514 \\
\hline$p$ & 0.0004 & 0.0163 & 0.0084 & 0.0056 & 0.0204 & 0.0212 \\
\hline$p<0.05$ & * & * & * & * & * & \\
\hline$p<0.01$ & ** & & ** & ** & & \\
\hline
\end{tabular}


Figure 6. Probability functions of loss of closed natural forest for six factors, derived by FRCA.
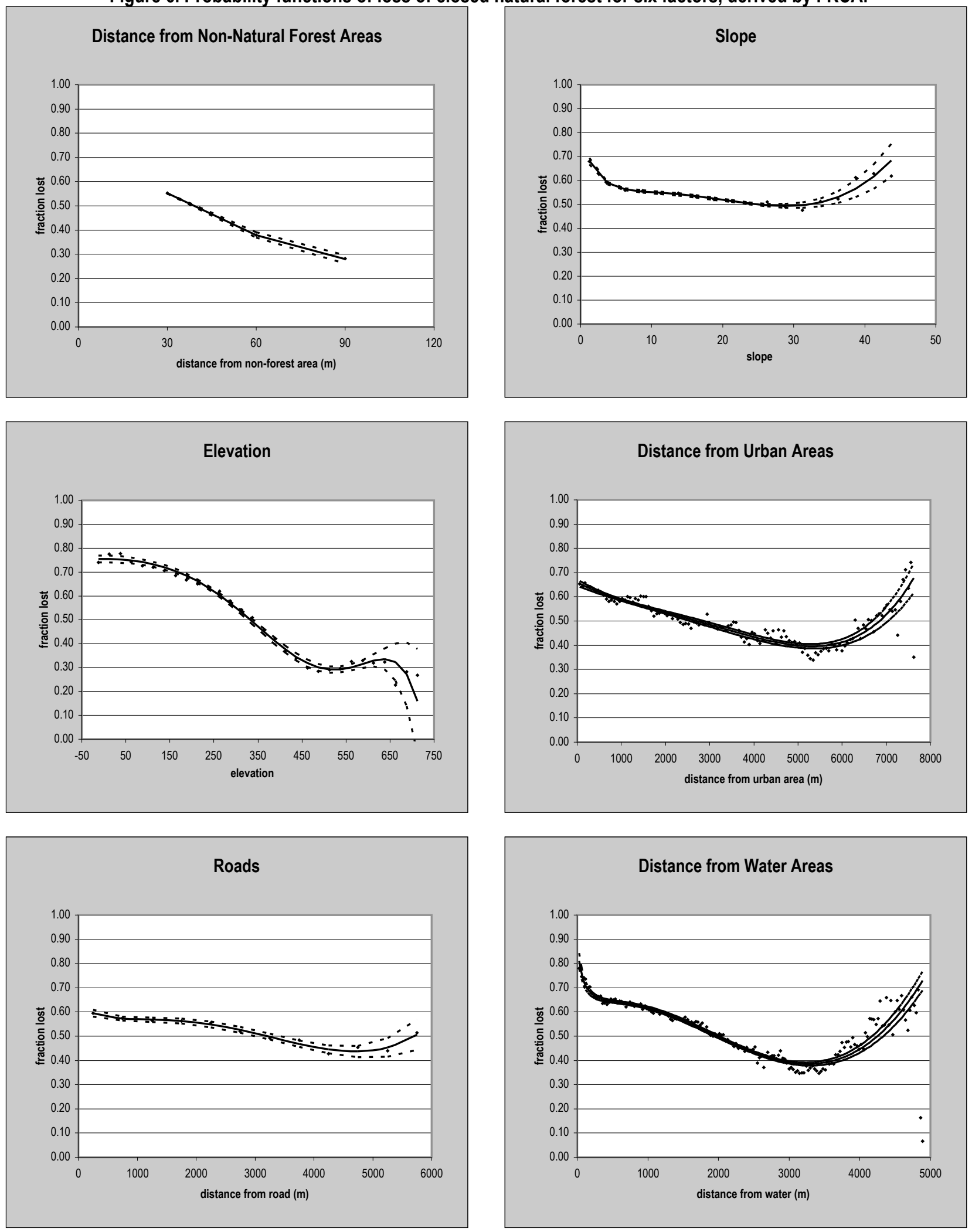


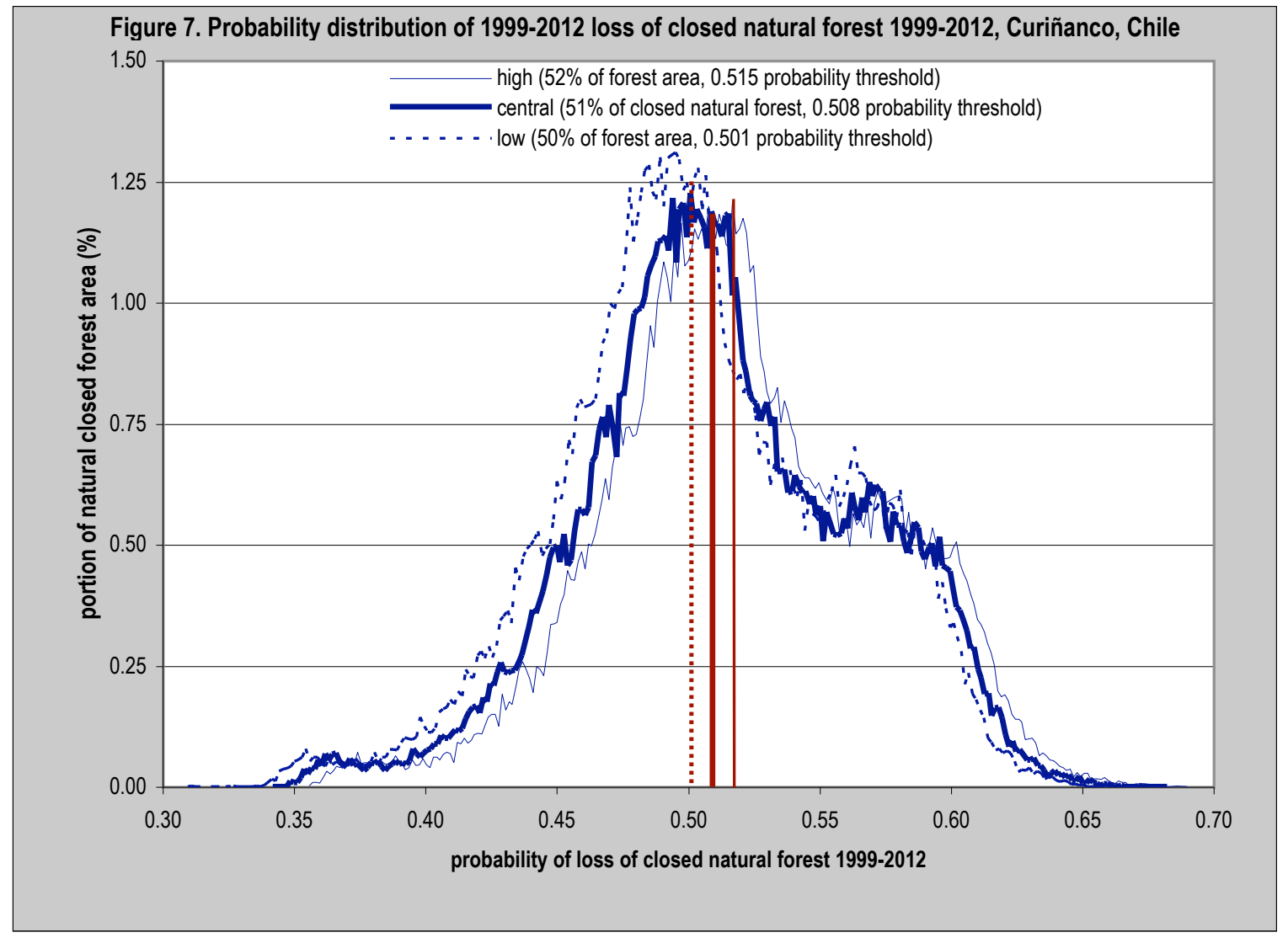


Figure 8.

\section{Curiñanco, Chile}

$3^{\circ} 30^{\prime}$

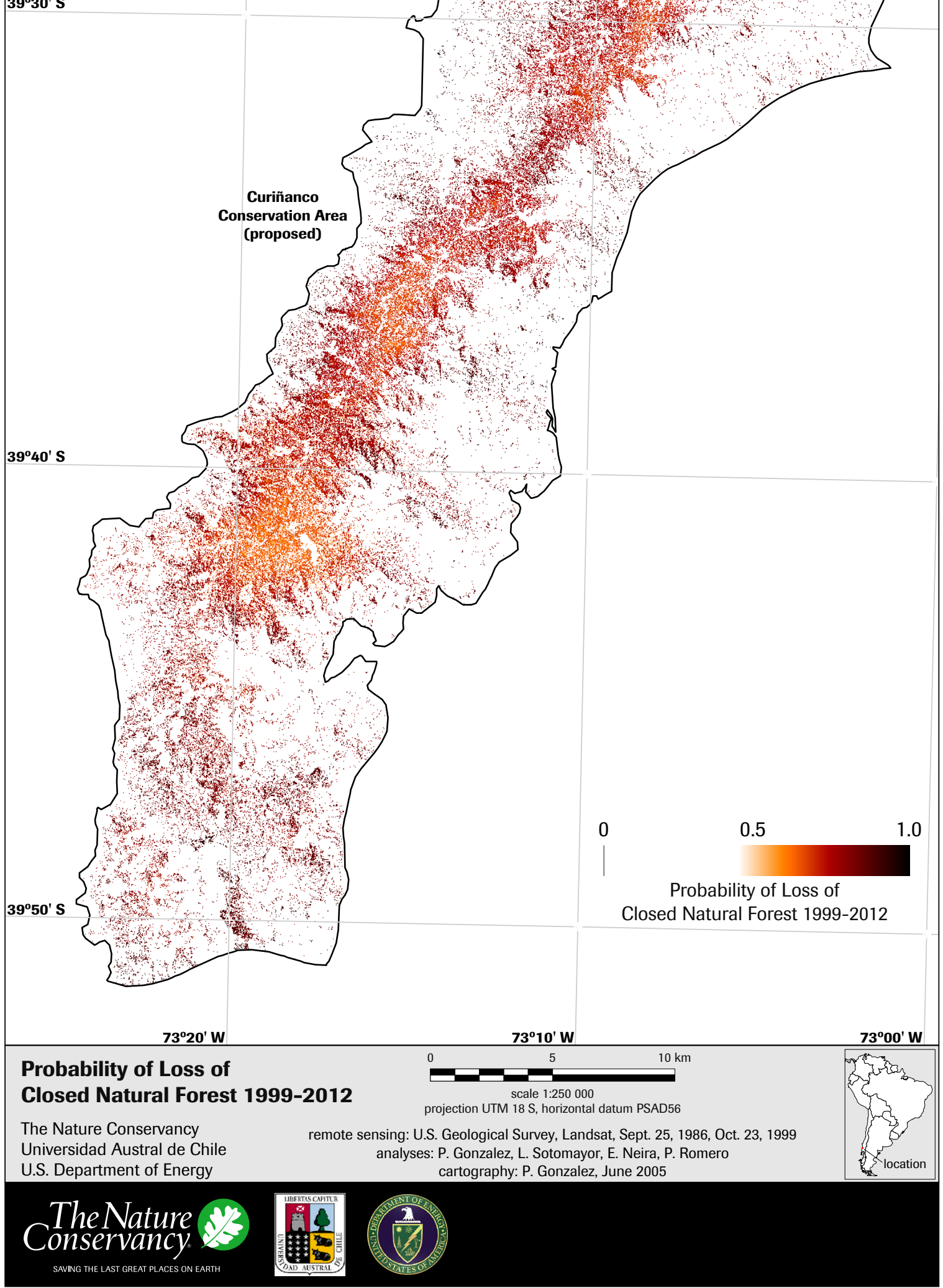


Figure 9.

\section{Curiñanco, Chile}

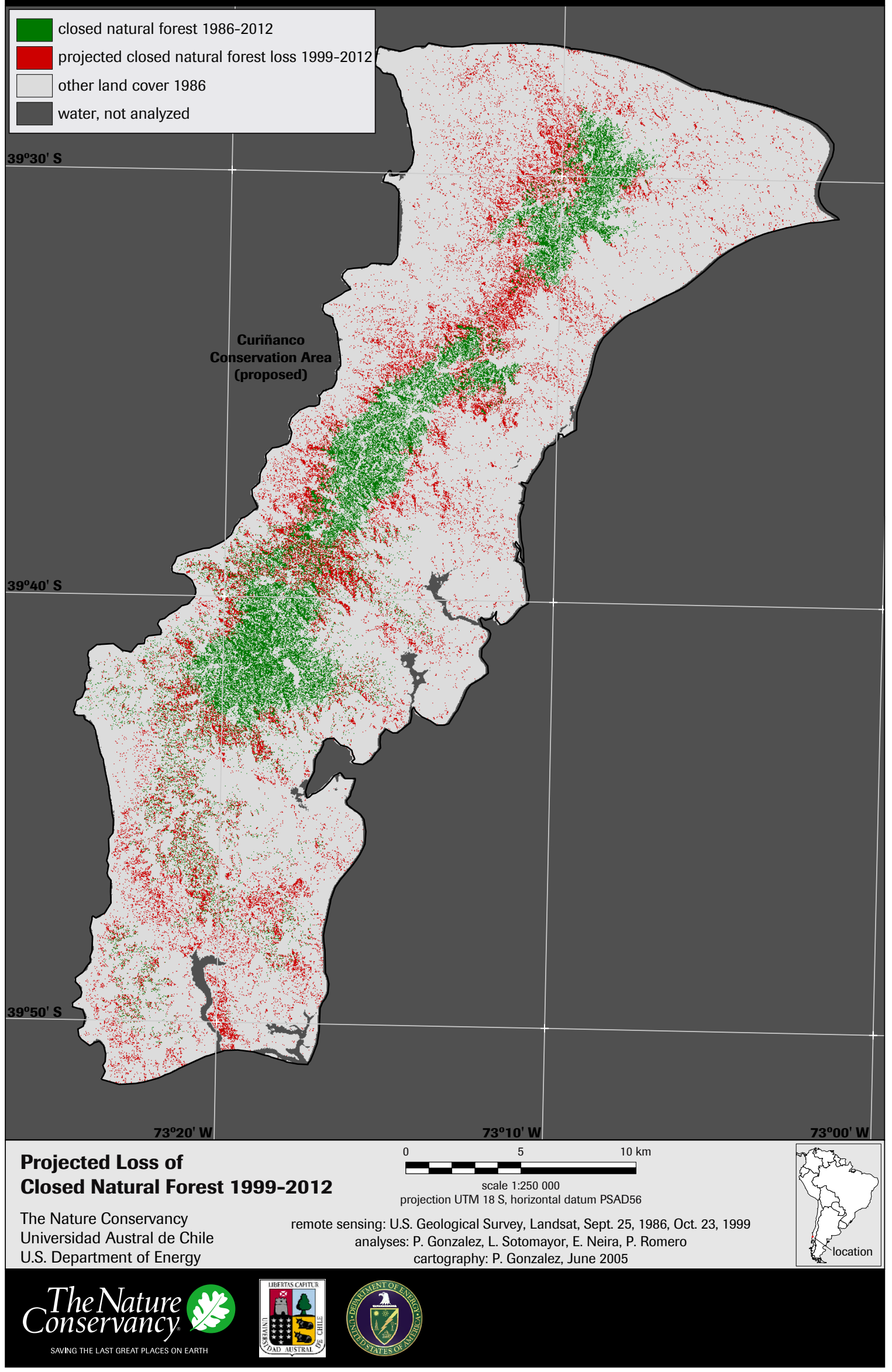




\section{Comparison of Three Methods}

The three methods projected different future carbon baseline emissions from continued loss of existing closed natural forest. Extrapolation from Landsat estimated a further loss of 5000 ha and $520000 \mathrm{t}$ carbon from closed natural forest in the period 1999-2012; Geomod modeled a loss of 2500 ha and $250000 \mathrm{t}$; FRCA projected a loss of $4700 \pm 100$ ha and $480000 \mathrm{t}$ (maximum $760000 \mathrm{t}$, minimum $220000 \mathrm{t}$ ) (Table 10). Because future baseline carbon emissions are directly proportional to the projected rate of loss of closed natural forest, the objective of a carbon baseline analysis is to estimate future rates of deforestation and reforestation. Both extrapolation from Landsat and Geomod, however, assume a future deforestation rate. FRCA offers the only method that calculates the deforestation rate as a dependent variable rather than assuming a deforestation rate as an independent variable.

FRCA projects a central estimate only slightly lower than the 'business as usual' case of extrapolation from Landsat change detection. Geomod projects only half of the baseline carbon emissions as the other two methods. Presumably, it assigned forest loss to pixels outside of the Curiñanco area.

FRCA is the only method that provides a measure of statistical error of the future projection in addition to the measurement error of the forest inventories. Both the baseline carbon emissions estimates from extrapolation from Landsat and Geomod fall within the high-low range of FRCA projections.

Three other technical differences separate Geomod and FRCA. First, Geomod allows the selection of administrative and other non-ecological units as areas of analysis. On the other hand, FRCA recognizes the need to select a unit of analysis of similar ecological and land management characteristics in order to analyze an area where deforestation and reforestation factors operate in similar ways and to minimize confounding factors. Second, Geomod allows the use of qualitative, non-dimensional attributes, such as administrative areas or categories of potential soil degradation. In contrast, recognizing that the index numbers assigned to qualitative variables are not necessarily proportional to real phenomena, FRCA requires the use of quantitative factors, such as distance from roads. Third, while Geomod uses trial-and-error to assign weights among different attributes, FRCA uses a multivariate statistical test to objectively calculate the weights of different factors in explaining observed deforestation and reforestation.

In order to evaluate the practical aspects of each method, we recorded the labor time spent on analytical tasks. Because time spent on a task may decrease as the education level of a worker increases, we also calculated a weighted estimate of hours normalized to the wage level of a Bachelors' degree holder. Note that another project conducted the extensive forest inventories, measured the carbon content of biomass constituents, and developed species-specific allometric equations (Gayoso et al. 2002). We only tabulated the minimal additional data analysis needed for the remote sensing analyses.

Extrapolation for Landsat required 90 actual days or 120 days normalized to Bachelor degree level wages (Table 11); Geomod required 240 actual days or 310 normalized days; FRCA required 110 actual days or 170 normalized days. So, Geomod required almost twice the amount of time as FRCA and three times the amount of time as extrapolation from Landsat. The difficulties that team members experienced with the MS-DOS version of Geomod 
greatly increased the time required for that method. Geomod still took the longest time of the three methods, even excluding the time spent on Geomod-MS-DOS.

In terms of ease of use, extrapolation from Landsat proved to be the easiest method, required the least amount of time, knowledge, or software. Geomod-Idrisi should be easier than our team experienced. It is integrated as an extension into the software. Users only need to process the raster data and run modeling iterations. In practice, however, our team members needed to buy and learn Idrisi, a software program that is not used very widely (Daratech 2002). In addition, out team members thought that the Idrisi manual did not provide the necessary information to properly run Geomod. Only the Geomod training session allowed them to use the extension.

FRCA proved to be of intermediate ease of use between extrapolation from Landsat and Geomod. It does not require much time, but it does require high skills in forestry, remote sensing, and statistics. So far, the Nature Conservancy has only used FRCA for the proposed Selva Central project, Peru, and for Curiñanco, Chile.

Table 10. Comparison of three estimates of change in closed natural forest area and forest carbon, 1999-2012.

\begin{tabular}{|c|c|}
\hline observation from Landsat & \\
\hline original area in 1986 & 20000 ha \\
\hline unchanged area remaining in 1999 & 9200 ha \\
\hline rate of loss (observed in analysis area) & $0.042 \mathrm{y}^{-1}$ \\
\hline initial forest carbon stock & $7600000 t$ \\
\hline forest carbon lost & $1100000 t$ \\
\hline extrapolation from Landsat & \\
\hline area remaining in 2012 & 4100 ha \\
\hline area lost 1999-2012 & 5000 ha \\
\hline rate of loss (assumed equal to $1986-1999$ analysis area) & $0.042 y^{-1}$ \\
\hline forest carbon lost & $520000 \mathrm{t}$ \\
\hline modeling by Geomod & \\
\hline area remaining in 2012 & 6700 ha \\
\hline area lost 1999-2012 & 2500 ha \\
\hline rate of loss (assumed equal to $1986-1999$ administrative area) & $0.031 \mathrm{y}^{-1}$ \\
\hline forest carbon lost & $250000 \mathrm{t}$ \\
\hline projection from FRCA & \\
\hline central estimate & \\
\hline area remaining in 2012 & 4500 ha \\
\hline area lost 1999-2012 & 4700 ha \\
\hline rate of loss (assumed equal to $1986-1999$ analysis area) & $0.039 y^{-1}$ \\
\hline forest carbon lost & $480000 \mathrm{t}$ \\
\hline high estimate & \\
\hline area remaining in 2012 & 4400 ha \\
\hline area lost 1999-2012 & 4800 ha \\
\hline rate of loss (assumed equal to 1986-1999 analysis area) & $0.040 y^{-1}$ \\
\hline forest carbon lost & $760000 \mathrm{t}$ \\
\hline low estimate & \\
\hline area remaining in 2012 & 4540 ha \\
\hline area lost 1999-2012 & 4600 ha \\
\hline rate of loss (assumed equal to 1986-1999 analysis area) & $0.039 y^{-1}$ \\
\hline forest carbon lost & $220000 \mathrm{t}$ \\
\hline
\end{tabular}


Table 11. Comparison of labor requirements for three methods. The weighted hours are normalized to the wage level of a Bachelors' degree holder. Note that another project conducted extensive forest inventories, measured the carbon content of biomass constituents, and developed species-specific allometric equations. The table reflects the minimal additional data analysis needed for the remote sensing analyses.

\begin{tabular}{lrrrrrrr}
\hline Worker & JG & PG & AL & PR & EN & LS & total weighted \\
\hline Education Level & Ph.D. & Ph.D. & Ph.D. & B.S. & M.S. & M.S. & \\
Estimated wage weight & 2 & 2 & 2 & 1 & 1.5 & 1.5 & \\
\hline
\end{tabular}

Labor for each task (days)

Forest inventory analyses of existing data

$15 \quad 1$

32

Landsat

Landsat processing, georegistration

Initial Landsat supervised classification

Supervision of Landsat analyses

Field survey of vegetation types

Final Landsat supervised classification

Landsat deforestation analysis

total Landsat

Geomod

Forest inventory analyses (from above)

Landsat (from above)

Geomod training

Supervision of Geomod analyses

Develop files of Geomod drivers

Modeling with Geomod-MS-DOS version

Modeling with Geomod-Idrisi version

total Geomod

\begin{tabular}{|c|c|c|c|c|c|c|c|}
\hline & & & & & $\begin{array}{l}5 \\
5\end{array}$ & $\begin{array}{l}0 \\
5 \\
5\end{array}$ & 0 \\
\hline & & 5 & & & & & \\
\hline & & & 10 & 10 & 10 & 30 & 40 \\
\hline & & & 15 & 10 & 2 & 27 & 33 \\
\hline & 2 & & 10 & 5 & & 17 & 22 \\
\hline 0 & 2 & 5 & 35 & 25 & 22 & 89 & 120 \\
\hline & & & & & & 0 & \\
\hline 15 & 1 & & & & & 16 & 32 \\
\hline 0 & 2 & 5 & 35 & 25 & 22 & 89 & 120 \\
\hline & & & 3 & 3 & & 6 & \\
\hline & & 10 & & & & 10 & 20 \\
\hline & & & 15 & 7 & 1 & 23 & 27 \\
\hline & & & 45 & 22 & 1 & 68 & 80 \\
\hline & & & 15 & 7 & 1 & 23 & 27 \\
\hline 15 & 3 & 15 & 113 & 64 & 25 & 235 & 313 \\
\hline & & & & & & 0 & 0 \\
\hline 15 & 1 & & & & & 16 & 32 \\
\hline 0 & 2 & 5 & 35 & 25 & 22 & 89 & 120 \\
\hline & 4 & & & & & 4 & \\
\hline & 1 & & & & & 1 & 2 \\
\hline & 4 & & & & & 4 & 8 \\
\hline 15 & 12 & 5 & 35 & 25 & 22 & 114 & 170 \\
\hline 30 & 24 & 20 & 148 & 89 & 47 & 353 & 500 \\
\hline
\end{tabular}

\section{Conclusion}

For organizations with limited time and financing, extrapolation from Landsat change provides a costeffective method. Organizations with more skill, time, and financing could use Forest Restoration Carbon Analysis (FRCA), the only method where that calculates the deforestation rate as a dependent variable rather than assuming a deforestation rate as an independent variable.

Our experiences suggest the following best practices for projecting future baseline carbon sequestration and emissions from forest restoration and conservation projects:

1. Integrate forest inventory and remote sensing tasks from the beginning of the analysis. Match remote-sensing derived land cover classes to forest inventory classes. 
2. Define an analysis area using ecological characteristics in order to analyze an area where deforestation and reforestation factors operate in similar ways and to minimize confounding factors.

3. Employ geographic information systems (GIS) software applications that are standard and widely used.

4. Use species-specific allometric equations and wood densities developed for local species in order to produce the most accurate estimates of forest carbon.

In conclusion, we must never fail to remember that projecting future carbon baseline sequestration and emissions is an attempt to predict the future, which is impossible. Still, we can develop realistic and scientifically valid estimates of forest carbon trends. Then, we can monitor the results over time to record what really happens.

\section{References}

Cattell, R. B. 1966. The scree test for the number of factors. Multivariate Behavioral Research 1: 245-276.

Comité Nacional Pro Defensa de la Fauna y la Flora (CODEFF). 2002. Plan de Manejo Área Silvestre Privada Protegida Punta Curiñanco. CODEFF, Valdivia, Chile.

Corporación Nacional Forestal (CONAF), Comisión Nacional del Medio Ambiente (CONAMA), and Banco Internacional de Reconstrucción y Fomento (BIRF). 1999. Catastro y Evaluación de los Recursos Vegetacionales Nativos de Chile. Universidad Austral de Chile, Pontificia Universidad Católica de Chile, Universidad Católica de Temuco, Santiago, Chile.

Corti, D. 1996. Caracterización y crecimiento de un renoval de roble (Nothofagus obliqua (Mirb.) Oerst.) lingue (Persea lingue (R. et P.) Nees ex Kopp), y radal (Lomatia hirsuta (Lam.) Diels ex Macbr.), en la comuna de Loncoche, Novena Región. Tesis, Facultad de Ciencias Forestales, Universidad Austral de Chile, Valdivia, Chile.

Corvalán, P. 1987. El Canelo: Una alternativa de desarrollo en la Décima Región. Fondo de Investigación Agropecuaria, Universidad de Chile, Santiago, Chile.

Daratech, Inc. 2002. Geographic Information Systems: Markets and Opportunities 2003. Daratech, Inc. Cambridge, MA.

Donoso, P. 1988. Caracterización, crecimiento y proposiciones silviculturales para comunidades de Nothofagus en el áreas de protección Radal 7 tazas, VII Región. Tesis, Facultad de Ciencias Forestales, Universidad Austral de Chile, Valdivia, Chile.

Emanuelli, P. 1999. Funciones generales de volumen para la Reserva Nacional Valdivia. Corporación Nacional Forestal, Santiago, Chile.

Gantz, C. 1994. Caracterización, crecimiento, e intervenciones silvícolas en un renoval mixto de monte bajo, del tipo Siempreverde, provincia de Valdivia. Tesis, Facultad de Ciencias Forestales, Universidad Austral de Chile, Valdivia, Chile. 
Gayoso, J., J. Guerra, and D. Alarcón. 2002. Contenido de carbono y funciones de biomasa en especies natives y exóticas. Universidad Austral de Chile, Valdivia, Chile.

Gayoso, J. and B. Schlegel. 2003. Estudio de línea de base de carbono: Carbono en bosques nativos, matorrales y praderas de la Décima Región de Chile. Universidad Austral de Chile, Valdivia, Chile.

Gonzalez, P., B. Kroll, and C.R. Vargas. 2004. Forest restoration carbon analysis in moist tropical forest at La Selva Central, Peru. Abstracts of the 89th Annual Meeting of the Ecological Society of America, August 1-6, 2004. Ecological Society of America, Washington, DC.

Hotelling, H. 1933. Analysis of a complex of statistical variables into principal components. Journal of Educational Psychology 24: 417-441, 498-520.

Howarth, P.J. and G.M. Wickware. 1981. Procedures for change detection using Landsat digital data. International Journal of Remote Sensing 2: 277-291.

Intergovernmental Panel on Climate Change (IPCC). 2001a. Climate Change 2001: The Scientific Basis. Cambridge University Press, Cambridge, UK.

Intergovernmental Panel on Climate Change (IPCC). 2001b. Climate Change 2001: Impacts, Adaptation, and Vulnerability. Cambridge University Press, Cambridge, UK.

Iroumé, A., A. Huber, and K. Schulz. 2005. Summer flows in experimental catchments with different forest covers, Chile. Journal of Hydrology 300: 300-313.

Lara, A., E. Neira, and C. Echeverría. 2002. Levantamiento de una base de datos para la implementación piloto de sistema de información para el manejo sustentable de los recursos naturales renovables y la conservación de la biodiversidad en la X Región de Los Lagos. Universidad Austral de Chile, Valdivia, Chile.

Laurance, W.F., A.K.M. Albernaz, G. Schroth, P.M. Fearnside, S. Bergen, E.M. Venticinque, and C. Da Costa. 2002. Predictors of deforestation in the Brazilian Amazon. Journal of Biogeography 29: 1-12.

Loguercio, G.A. 1997. Erhaltung der Baumart "ciprés de la cordillera" Austrocedrus chilensis (D. Don) Florin et Boutelje durch nachhaltige Nutzung. Dissertation. Waldbau und Forsteinrichtungsinstitut, Forstwissenschaftliche Fakultät, Ludwick Maximilains-Universität, München, Germany.

Lu, D., P. Mausel, E. Brondi'zio, and E. Moran. 2004. Change detection techniques. International Journal of Remote Sensing 25: 2365-2407.

Magni, R. 1995. Acumulación de biomasa y nutrientes en un bosque mixto natural de lenga (Nothofagus pumilio (Poepp. et Endl.) Krasser) y Coigüe de Magallanes (Nothofagus betuloides (Mirb.) Oerst) en la XII región. Tesis, Facultad de Ciencias Agrarias y Forestales, Universidad de Chile, Santiago, Chile.

Marticorena, C. and R. Rodríguez. 1995. Flora de Chile, Vol. 1 Pteridophyta-Gymnospermae. Universidad de Concepción, Concepción, Chile.

Neira, E., P. Romero, and A. Lara. 2004. Complementación del estudio para el diseño de una línea de base para captura de Carbono en la Xma Región de Chile. Universidad Austral de Chile, Valdivia, Chile. 
Pearson, K. 1901. On lines and planes of closest fit to systems of points in space. Philosophical Magazine 6: 559572.

Pedrasa, M. 1989. Producción de biomasa y circulación de nutrientes en un rodal de Nothofagus alessandri Espinoza (Ruil) en la zona de Constitución. Tesis, Facultad de Ciencias Agrarias y Forestales, Universidad de Chile, Santiago, Chile.

Pérez, V. 1983. Manual de propiedades físicas y mecánicas de las maderas chilenas. Corporación Nacional Forestal, Santiago, Chile.

Pontius Jr., R.G., J.D. Cornell, C.A.S. Hall. 2001. Modeling the spatial pattern of land-use change with GEOMOD2: Application and validation for Costa Rica. Agriculture, Ecosystems, and Environment 85: 191-203.

Rodríguez, R., G. Hofmann, M. Espinosa, and D. Ríos. 2003. Biomass partitioning and leaf area of Pinus radiata trees subjected to silvopastoral and conventional forestry in the VI region, Chile. Revista Chilena de Historia Natural 76: 437-449.

Schlatter, J. and E. Neira. 2001. Elaboración de prediagnóstico nacional del componente suelos para la discusión regional de la política para la sustentabilidad ambiental del patrimonio natural renovable. Universidad Austral de Chile, Valdivia, Chile.

Toral, M., U. Kannegiesser, and R. Rosende. 1988. Biomasa y boldina en Boldo (Peumus boldus Mol) VII región. Ciencia e Investigación Forestal 2: 15-25.

Toro, J. and S. Gessel. 1999. Radiata pine plantations in Chile. New Forests 18: 33-44.

United States Geological Survey (USGS). 2003. Landsat: A global land observing program. USGS, Reston, VA. United States Global Change Research Program (USGCRP). 2001. Climate Change Impacts on the United States: The Potential Consequences of Climate Variability and Change. Cambridge University Press, Cambridge, UK.

Urzuá, E. 1980. Utilización silvo agropecuaria de los terrenos ñadi. Informe forestal zona ñadi. Provincia de Llanquihue. Universidad Austral de Chile, Valdivia, Chile.

Valenzuela, P. 1995. Biomasa y contenido de nutrientes en un bosque multietáneo de lenga (Nothofagus pumilio (Poepp. et Endl.) Krasser) en la provincia de Magallanes, XII Región. Tesis, Facultad de Ciencias Agrarias y Forestales, Universidad de Chile, Santiago, Chile.

Vergara, G. and J. Gayoso. 2004. Efecto de factores físico-sociales sobre la degradación del bosque nativo. Bosque 25: $43-52$. 